\title{
Processes leading to deep convection and sensitivity to sea-state representation during HyMeX IOP8 heavy precipitation event
}

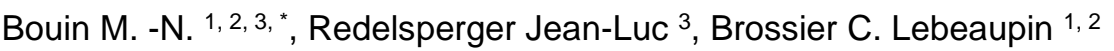

\author{
1 Meteo France, CNRM, UMR 3589, Toulouse, France. \\ ${ }^{2}$ CNRS, Toulouse, France. \\ ${ }^{3}$ CNRS, IFREMER, IRD, UBO,Lab Oceanog Phys \& Spatiale,UMR 6523,IUEM, Plouzane, France. \\ *Corresponding author : M. -N Bouin, email address : marie-noelle.bouin@meteo.fr
}

\begin{abstract}
:
During the first observation period of the HyMeX programme, the Mediterranean coasts of Spain were impacted by several heavy precipitating events (HPEs). The most damaging one occurred during IOP 8 resulting in cumulative rainfall amounts over $180 \mathrm{~mm}$ in the area of Murcia Valencia. Numerical simulations using a high-resolution atmospheric model provide a very realistic representation of the mesoscale convective systems (MCSs) at the origin of this HPE and of the associated low-level conditions, consisting in two cold sectors surrounding a warm sector. This study provides a detailed analysis of the mechanisms of deep convection initiation and maintenance between 1200 UTC 28 September and 0000 UTC 29 September 2012. On the coastal mountainous area, the conditionally unstable inflow feeding the MCS is uplifted by the relief whereas at sea, a strong low-level convergence plays the same role. At the coast, cold pools are generated and strengthened by a strong low-level jet (LLJ) carrying cold dense air parcels from the Gulf of Lion and by evaporation and cooling under the precipitating systems. These cold pools play a key role in triggering the deep convection, either by directly uplifting the air masses or by deflecting the inflow horizontally. They largely control the localisation and distribution of the heavy precipitation at sea near Valencia. A weak barrier wind over the cold pools and a secondary cyclonic circulation result in a bending of the convergence line at sea, in agreement with radar observations.

A sensitivity study to a more realistic representation of the sea state in the air sea exchanges shows that the LLJ is decelerated by the increased sea-surface roughness, resulting in cold pools extending further at sea and shifting the precipitation patterns $50 \mathrm{~km}$ offshore.
\end{abstract}

Keywords : heavy precipitation event, HyMeX, mesoscale convective system, sea state, Mediterranean Sea, air sea exchanges, cold pool, deep convection 
31 Heavy precipitation events (HPEs) affect regularly the western Mediterranean coastal regions in

32 autumn and result often in flash flooding and landslides susceptible to produce thousands of

33 millions euros damages and even casualties (e.g. Ricard et al., 2012; Llasat et al., 2013). Daily

34 rainfall cumulative amounts higher than $150 \mathrm{~mm}$ are frequently observed as generated by multi-cell

35 quasi-stationary mesoscale convective systems (MCSs; e.g. Ducrocq et al., 2008; Buzzi et al.,

36 2014). These MCSs generally develop on the eastern edge of an upper-level trough extending from

37 the British Isles to off the Iberian Peninsula associated with potential vorticity anomaly likely to

38 generate low-level instability (Nuissier et al., 2011; Duffourg et al., 2016). A major ingredient

39 common to all HPEs is the conditionally unstable moist marine flow extracting energy from the

40 western Mediterranean sea surface, which is at its warmest in autumn and acts as a heat and

41 moisture reservoir. This flow is directed towards the Spanish, Italian or French mountainous coastal

42 regions where it undergoes continuously renewed lifting: the same local mechanisms enable

43 uplifting at the same place. This lifting marks the onset of deep convection and precipitation on the

44 coastal areas, and is a key ingredient of quasi stationarity. The complexity of the mountainous

45 terrain and coastal topography has been demonstrated to be a factor influencing the orographic 
46 triggering of the convection, along with the characteristics of the low-level inflow (Miglietta and

47 Rotunno, 2010; 2012; Bresson et al., 2012). The precise role of the relief in determining the

48 location and distribution of the heavy precipitation has been recently demonstrated on the

49 Mediterranean islands (Corsica and Sardinia; Barthlott and Kirshbaum, 2013) and on the alpine

50 foothills on the northern Adriatic coastal area (Di Muzio, 2014; Davolio et al., 2016). Low-level

51 convergence upstream of the relief or over the sea is another mechanism triggering deep convection

52 (Ducrocq et al., 2008; Duffourg et al., 2016).

53 Besides the direct orographic forcing by the elevated terrain behind the coasts and the low-

54 level moisture convergence at sea, the formation of a low-level cold pool is another lifting

55 mechanism susceptible to favour deep convection. Cold pools are usually generated by rainfall

56 evaporation in subsaturated air masses around $1.5 \mathrm{~km}$ above sea level (asl - Ducrocq et al., 2008;

57 Bresson et al., 2012). The resulting cold air parcels propagate downwards and spread to form cold

58 pools. This cold pool, which is denser than the incoming low-level flow, acts like a relief by

59 blocking and uplifting the moist and warm flow, resulting in a shift of the deep convection

60 upstream. This cooling mechanism and the resulting cold pool has been demonstrated by a

61 sensitivity study to be the main mesoscale ingredient for the quasi-stationarity of a MCS that

62 occurred in September 2002 over the Gard plains rather than over the Massif Central foothills

63 (Ducrocq et al., 2008). Cold pools may interact or compete with orographic lifting to determine the

64 positioning of heavy precipitation depending upon the characteristics of the incoming conditionally

65 unstable low-level flow. Air lifting and triggering of deep convection by cold pools are especially

66 efficient when the incoming flow is relatively dry or weak (relative humidity around $85 \%$ and low-

67 level wind around $15 \mathrm{~m} \mathrm{~s}^{-1}$, Bresson et al., 2012). Besides direct lifting of the air masses, cold pools

68 may also deflect horizontally the incoming flow and favour or reinforce the low-level convergence

69 (Duffourg et al., 2016). 
70 Better understanding these competing or interacting processes at the origin of deep

71 convection and heavy precipitation on the Mediterranean coasts in autumn is part of the objectives

72 of the HyMeX (HYdrological cycle in the Mediterranean EXperiment) programme. HyMeX is an

73 international programme dedicated to the study of the hydrological cycle and related processes in

74 the Mediterranean (Drobinski et al., 2014). The first special observation period (SOP1) in autumn

752012 aimed at monitoring and studying these heavy precipitating events over the Mediterranean

76 coastal regions (Ducrocq et al., 2014). Several Intensive Operation Periods (IOPs) focused on the

77 observation of the MCSs at the origin of these high-impact events and on investigating the

78 associated processes.

79 IOP8 on 28 September 2012 led to heavy precipitation on the Spanish Mediterranean coasts 80 (more than $200 \mathrm{~mm}(24 \mathrm{~h})^{-1}$ in Andalusia, $190 \mathrm{~mm}(24 \mathrm{~h})^{-1}$ in the Murcia region and $140 \mathrm{~mm}(24 \mathrm{~h})^{-1}$

81 in Valencia) and was the most damaging event observed during the SOP1 (Jansà et al., 2014;

82 Ducrocq et al., 2016). The chronology of the event and an overview of the associated mechanisms

83 have been the subject of previous studies. Using high-resolution numerical modelling, Röhner et al.

84 (2016) identified orographic forcing as the main mechanism for the triggering of deep convection

85 over the coastal mountainous area, and strong low-level convergence as the mechanism at the origin

86 of deep convection at sea. Using backwards trajectories helped them to identify heat and moisture

87 local source for the conditionally unstable air masses in the Western Mediterranean basin for the last

88 and more damaging part of the event. Khodayar et al. (2016) evaluated the adequacy of

89 observational networks to provide information on the HPE. Describing the associated atmospheric

90 circulation and stratification at broad scale, they identified three different convergence mechanisms

91 leading to the development of deep convection over land, at the coast or at sea. These studies

92 showed that the representation of IOP8 using high-resolution numerical modelling is good, and that

93 its low-level dynamics is reasonably represented by the observations, making IOP8 a suitable case 
94 for process study and sensitivity tests. However, they provide a rather general view of the events. In 95 particular, none of these studies investigate in details the processes likely responsible for triggering 96 deep convection along the coasts or on the mountainous foothills and their interplay. Especially, the 97 presence of cold pools and their possible role in triggering deep convection are not included in the 98 previous IOP8 studies.

99 Consequently, the first objective of this study is to provide a detailed analysis of the 100 processes at the origin of the heavy precipitation that impacted the Murcia and Valencia region 101 between 1200 UTC on 28 September 2012 and 0000 UTC on 29 September 2012. The study area 102 and associated timing were chosen because they are susceptible to involve most of the uplifting 103 processes described above. It constitutes a good test bed for investigating the interaction of these 104 mechanisms initiating and maintaining deep convection on the mountainous range, over sea and on 105 the coast. The effect of the waves generated by the wind (hereafter wind sea) on the low-level flow 106 is usually implicitly represented in atmospheric models through the Charnock parameter and 107 roughness length (see Eq.1 in section 3.1). As shown by a previous study on the HyMeX SOP1 108 IOP16a (Thévenot et al. 2016), a more realistic representation of the wind sea may have a 109 significant impact on the turbulent air-sea exchanges and in the low-level flow. These authors 110 obtained a slowing down of the low-level flow feeding the MCSs, resulting in a shift of the 111 precipitation pattern towards sea, in better agreement with the observations. The second objective of 112 the present study is thus to assess the impact of a better representation of the wind sea on the sea113 surface roughness, momentum and heat transfer between the ocean and the atmosphere, low-level 114 wind field and precipitation.

115 This paper is organized as follows. Section 2 provides an overview of the IOP8 with the 116 synoptic context leading to the development of the HPE, the chronology of the events and a 117 summary of the atmospheric conditions. In section 3, the numerical simulations performed on this 
118 case study are presented together with their evaluation using satellite and field campaign

119 observations. The outputs of the reference simulation are analysed in section 4 to provide a detailed

120 description of the processes at the origin of deep convection and heavy precipitation on the Murcia-

121 Valencia region. The impact of the representation of the sea state in the parameterization of the air-

122 sea exchanges on these processes and on the precipitation is presented in section 5. Section 6

123 concludes with a summary of the results.

124 2. IOP8 overview

125 2.1. Synoptic context

126 The synoptic situation of the HyMeX IOP8 is characterized by an upper-level cut-off low over

127 southern Portugal at 0000 UTC on 28 September 2012, progressing eastwards and reaching eastern

128 Spain at 0000 UTC on 29 September 2012 (see Fig. 1a for the ARPEGE - Action de Recherche

129 Petite Echelle Grande Echelle - analysis at 0000 UTC on 28 September, Fig. 1b for the synoptic

130 analysis at 1800 UTC). The associated warm and cold surface fronts progressed northwards over

131 the southwestern Mediterranean basin between 0600 UTC on 28 September 2012 and 0000 UTC on

13229 September 2012.

\subsection{Chronology of the precipitating events}

134 The Spanish and Catalonian networks of rain gauges (MeteoCat) provide hourly observations of the

135 precipitation amounts with a good geographical coverage (Fig. 2; see also Fig. 3b for the names of 136 major cities and geographical locations). Heavy precipitation affected Andalusia in the morning of 137 the 28 September between 0600 and 1200 UTC, with cumulated amount above $200 \mathrm{~mm}$ (Fig. 2a, 138 2b), then progressed eastwards to the Murcia region between 1200 and 1800 UTC (Fig. 2c, 2d) with 139 cumulated amount of $190 \mathrm{~mm}$. The Valencia region was also affected by heavy rain between 1800 140 and 2400 UTC on the same day (Fig. 2e, 2f). 


\section{$141 \quad 2.3$ Mesoscale convective systems and low level conditions}

142 The multi-cell MCS responsible for the heavy rainfall on the Murcia and Valencia region originally

143 developed around 1100 UTC over Almeria and progressed northeastwards before splitting into

144 several systems around 1600 UTC. The near-surface wind field, as estimated by the ASCAT

145 (Advanced SCATterometer, EUMETSAT) scatterometer onboard the Metop-A satellite between

1462100 UTC on 28 September and 0000 UTC on 29 September shows three different low-level flows

147 (Fig. 3a). North of the Mallorca island, a flow initiates in the Gulf of Lion with moderate-to-fairly-

148 strong northerly-to-northeasterly winds converging with a slightly stronger northeasterly flow north

149 of the Balearic Islands. This moderate low-level flow corresponds to the cold sector ahead of the

150 warm front (hereafter ahead cold sector; Fig. 1b) and is blowing from the right side to the left side

151 of the front. It reinforces locally to strong wind and is to some extent channeled between the

152 Balearic Islands and the coast of Catalonia, before reaching the coasts of the Valencia region. South

153 of Ibiza and between North Africa and the coasts of southeastern Spain, a southwesterly moderate

154 flow characterizes the cold sector behind the cold front (hereafter rear cold sector). Between these

155 two regions, the warm sector is characterized by a light-to-moderate easterly-to-northeasterly low-

156 level flow. This low-level flow distribution results in a strong surface convergence line located

157 along the warm front between the warm and moist easterly flow on the warm sector and the rapid

158 southwesterly flow between southern Spain and North Africa. In the following, we focus on the

159 Murcia-Valencia region and we investigate the processes at the origin of deep convection

160 (especially the possible role of cold pools) using the modelling tools that are presented in the next 161 part. 


\section{3. Meso-NH simulations}

\section{3.1. Meso-NH model and set-up}

164 The numerical simulations were performed with the non hydrostatic numerical research model 165 Meso-NH (Lafore et al., 1998). The Meso-NH model was run over a $1125 \times 1125 \mathrm{~km}^{2}$ domain 166 covering the western Mediterranean basin from Gibraltar to the west of Sardinia (Fig. 3b). It

167 encompasses the precipitating systems during their whole life-cycle as well as the different marine 168 low-level moisture-supplying flows. The horizontal grid has a $2.5-\mathrm{km}$ resolution, and the vertical 169 grid is defined with 55 stretched vertical levels (Gal-Chen and Somerville, 1975) up to $20 \mathrm{~km}$, with 17018 levels in the lowest $1500 \mathrm{~m}$ above the surface. The model resolution and associated physical 171 parameterization package are the same as those used in previous studies of HPEs using Meso-NH 172 (e.g. Nuissier et al., 2008, Thévenot et al., 2016, Duffourg et al., 2016).

173 The prognostic variables of the model are the three components of the wind, the dry potential 174 temperature, the turbulent kinetic energy and the mixing ratios of the water vapour and of five 175 different classes of hydrometeors (cloudwater, rainwater, primary ice, snow aggregates, and 176 graupel). The evolution of the water species are governed by a bulk microphysical scheme (Caniaux 177 et al., 1994; Pinty and Jabouille, 1998). The parameterization of the turbulence is based on a 1.5178 order closure (Cuxart et al., 2000) with the diagnostic mixing length option following Bougeault 179 and Lacarrère (1989). Thanks to its high horizontal resolution, the atmospheric deep convection is 180 explicitly solved by the model. The surface conditions and the air-surface exchanges are governed 181 by the SURFEX surface model (Masson et al., 2013). The sea-surface turbulent fluxes are 182 parameterized using the COARE 3.0 formula (Fairall et al., 2003). The sea-surface roughness is 183 related to the friction velocity $u *$ using the Charnock coefficient $\alpha_{c h}$ : 
184

$$
z_{0}=\alpha_{c h} \frac{u_{*}^{2}}{g}+0.11 \frac{v}{u_{*}}
$$

185

186

187

188

189

190

where $g$ is the gravitational acceleration and $v$ the kinematic viscosity.

\author{
where $g$ is the gravitational acceleration and $\nu$ the kinematic viscosity.
}

Simulations start on 28 September 2012 at 0000 UTC and last $24 \mathrm{~h}$. They are initialised and driven at their lateral boundaries every $3 \mathrm{~h}$ from the high-resolution AROME-WMED analyses (Application of Research to Operations at Mesoscale - Western Mediterranean; Fourrié et al., 2015). The sea-surface temperature (SST) field comes from the initial AROME-WMED analysis, which is built with the 2D Optimal Interpolation of in situ measurements CANARI (Code d'Analyse Nécessaire à Arpege pour ses Rejets et son Initialisation; Taillefer, 2002) blended with the Operational Sea Surface Temperature Ice Analysis (OSTIA; Donlon et al., 2012). This SST field remains constant during the $24-\mathrm{h}$ integration.

\title{
3.2 Sensitivity to sea state representation
}

In order to test the sensitivity of the boundary-layer processes and of the HPEs to the sea state, two simulations were performed with and without explicitly representing the wave impact into the surface turbulent fluxes parameterization. The methodology used here follows closely the one used by Thévenot et al. (2016) with the use of the sea state analyses taken from the run of the Wavewatch III ${ }^{\circledR}$ wave model (Ardhuin et al., 2010; Tolman, 2014) in the Previmer project framework (http://www.previmer.org) as a surface forcing of the Meso-NH/SURFEX model.

In the experiment with no wave impact (NOWAV hereafter, used throughout this study as a reference simulation), the COARE 3.0 algorithm is used with the formulation of the Charnock coefficient from Hare et al. (1999), i.e. $\alpha_{c h}$ is set to 0.011 for $10-\mathrm{m}$ wind speed below $10 \mathrm{~m} \mathrm{~s}^{-1}$, then increases linearly up to 0.018 at $18 \mathrm{~m} \mathrm{~s}^{-1}$, and remains constant for larger wind speeds. In the experiment with explicit wave representation (WW3_F hereafter), the formulation of Oost et al. 
206 (2002) is used with the wave peak period provided by the analysis every $3 \mathrm{~h}$ :

$$
\alpha_{c h}=50\left(c_{p} / u_{*}\right)^{-2.5}
$$

208 where $c_{p}$ is the wave phase velocity. The Wavewatch III ${ }^{\circledR}$ wave parameters have been compared 209 with two Météo-France buoy observations in the Gulf of Lion and Azur sites. Mean biases are of $210 \quad 0.16$ and $0.36 \mathrm{~m}$ for the significant wave height (root mean square $0.25 \mathrm{~m}$ ) and of 1.0 and $0.9 \mathrm{~s}$ for 211 the peak period (root mean square 0.6 and $0.5 \mathrm{~s}$ ), respectively. This level of agreement is 212 comparable to what has been obtained in a previous study (Thévenot et al., 2016) and makes us 213 confident in using these analysed parameters as a forcing representative of the actual sea state over 214 the western Mediterranean basin.

\section{Validation of the reference simulation}

216 The results of the NOWAV reference simulation were compared to observations in order to assess

217 the skill of the simulation in representing the processes and the chronology of the events. All the

218 observations used in this work were collected and have been made available in the HyMeX project 219 framework.

\section{4.1 Precipitation}

221 The observations used in this part are taken from the Spanish rain gauge network including the 222 dense network of METEOCAT. The amount and location of the precipitation simulated in NOWAV 223 display a good match with the rain gauge 3 -h cumulative precipitation from 0600 UTC on 28 224 September 2012 to 0000 UTC on 29 September 2012 (Fig. 2a to 2f). The maximum cumulative 225 amount observed by the rain gauges available for this study is $204 \mathrm{~mm}(24 \mathrm{~h})^{-1}$ over the whole 226 domain, that compares favourably with the maximum predicted by the NOWAV simulation of $227212 \mathrm{~mm}(24 \mathrm{~h})^{-1}$. To assess more precisely the skill of our two simulations, scores against rain gauge 
228 observations for the 24-h period starting at 0000 UTC on 28 September over the whole simulation

229 domain have been computed. The simulated daily rainfall amounts are extracted at the closest grid 230 point to the 1233 rain gauge stations. The mean bias, the standard deviation of the difference 231 (SDD), and the correlation coefficient $(r)$ are given in Table 1, as well as two categorical scores 232 widely used for assessing skills of precipitation forecast: the Equitable Threat Score (ETS; Schaefer, 233 1990) and the Hanssen and Kuipers discriminant (HK; Hanssen and Kuipers, 1965). Both scores 234 assess the ability of the model to detect rainfall amounts above a given threshold (see Table 1) and 235 give values between -1 and 1 . The thresholds used here correspond roughly to the 4-, 5- and 6236 quantiles in the observations. ETS excludes the probability of detecting an event by chance, values 237 equal to (resp. below) zero indicates that model skills are equal to (resp. below) a random forecast. 238 HK measures the accuracy of the forecast both for events and non events, $\mathrm{HK}=0$ corresponds to a 239 constant forecast and $\mathrm{HK}=-1$ to zero hits both for events and non-events forecasts.

240 The scores obtained here are high, showing that the representation of this event by our two 241 simulations is much better than random or constant forecast and performs very well in predicting 242 both events and non events.

\subsection{Low-level flow and stability}

244 The wind field at the first vertical level of the model over sea is compared with the wind field 245 obtained from the ASCAT scatterometer onboard Metop-A (Fig. 3) and shows a good agreement in 246 intensity and direction. Especially, the near-surface convergence line corresponding to the front 247 between Ibiza and Mallorca is well represented in the simulation, as well as the lower intensity of 248 the low-level wind in the warm sector area. Here and in the rest of the study the cold and warm 249 fronts are determined using the $2-\mathrm{m}$ temperature gradients. The occluded front is determined using 250 the low-level wind convergence. 
251 The radiosoundings performed in Palma de Mallorca and Barcelona on 28 September at 2521800 UTC and on 29 September at 0000 UTC are used to assess the skills of the NOWAV 253 simulation in reproducing the wind field at different levels and the air masses stability profiles from 254 the equivalent potential temperature $\left(\theta_{e}\right.$, Fig. 4). These radiosoundings were assimilated in the 255 AROME-WMED analyses used as large-scale forcing of our simulations (Fourrié et al., 2015). 256 Their impact on the NOWAV simulation is probably weak, since they occur late in the simulation 257 and far from the domain boundaries. Observed and simulated radiosounding profiles generally 258 agree well on the $\theta_{e}$ and wind values. In Barcelona, the simulated wind speed is systematically 259 lower than in observations especially at upper level, though the agreement on the direction is very 260 good. In particular, the veering of the wind at 1800 UTC from east-north-east at the surface to south 261 at $5000 \mathrm{~m}$ asl and south-west at upper level that can be observed on the two stations is well 262 reproduced by the simulation. The tropopause height is close to $12 \mathrm{~km}$ at both locations and times.

263 At 1800 UTC, the Palma sounding is still located in the cold sector ahead of the incoming 264 warm front (Fig. 4a). The ground equivalent potential temperature is $50-55^{\circ} \mathrm{C}$ in the simulation, 265 increasing up to $60^{\circ} \mathrm{C}$ at $1000 \mathrm{~m}$ asl, then decreasing to $50^{\circ} \mathrm{C}$ at $3000 \mathrm{~m}$ asl. The low-level wind is 266 northeasterly, close to $12 \mathrm{~m} \mathrm{~s}^{-1}$, weakening to $5 \mathrm{~m} \mathrm{~s}^{-1}$ at $2000 \mathrm{~m}$ asl. At 0000 UTC on 29 September 267 (Fig. 4b) Palma is now in the warm sector as shown by the increase of the surface $\theta_{e}$ up to $55-65{ }^{\circ} \mathrm{C}$ 268 in the simulation. The simulated potential temperature at low level is generally higher than in 269 observations though their profiles up to $3000 \mathrm{~m}$ asl are very similar. This warm and moist low-level 270 layer goes up to $2000 \mathrm{~m}$ asl with some instability remaining up to $4000 \mathrm{~m}$ asl in the simulated 271 profile. The low-level wind is weak (up to $4000 \mathrm{~m}$ asl) in the warm sector, as already noticed 272 (section 2.3 and Fig. 3).

273 The two Barcelona profiles exhibit a similar evolution between 1800 UTC and 0000 UTC 274 (Fig. 4c and d), with equivalent potential temperatures close to $40^{\circ} \mathrm{C}$ at the surface. Barcelona 
275 profiles are in the ahead cold sector at both time periods, with the occluded front approaching from 276 the south on 29 September at 0000 UTC. At both times the wind is weak from east close to the 277 ground, about $15 \mathrm{~m} \mathrm{~s}^{-1}$ at $1000 \mathrm{~m}$ asl, and from south to southeast at upper level. At $1800 \mathrm{UTC}$, the 278 low $-\theta_{e}$ air masses close to the ground transported from the sea by the northeasterly low-level flow 279 are topped by a thick layer of warmer, stable air $\left(\theta_{e}\right.$ close to $\left.55^{\circ} \mathrm{C}\right)$ from 700 to $3000 \mathrm{~m}$ asl. At 2800000 UTC on 29 September, the low- $\theta_{e}$ layer below $700 \mathrm{~m}$ asl is still present with a sharper vertical 281 gradient (likely maintained by the low-level cold and moist easterly flow) but the warmer air layer 282 located just above is now thinner with $\theta_{e}$ close to $50^{\circ} \mathrm{C}$ up from $2000 \mathrm{~m}$ asl. This can be explained 283 by a strong and homogeneous flow observed in the simulation outputs between 2000 and $4800 \mathrm{~m}$ 284 asl transporting drier air with $\theta_{e}$ below $48^{\circ} \mathrm{C}$ from the south of the western Mediterranean basin 285 (not shown).

286 In summary, the reference simulation succeeds in reproducing the stability $\left(\theta_{e}\right)$ variations 287 observed in the radiosoundings. The profiles of wind direction and wind speed at first order is also 288 well reproduced by the model (except in Barcelona for the wind speed). We consider in the 289 following that this simulation can be confidently used to investigate the fine-scale processes leading 290 to deep convection and heavy precipitation in the Murcia-Valencia region.

\section{5. Process study}

292 In this part, the reference simulation outputs are used to study the different processes at play on the 293 eastern Spanish coast between Murcia and Valencia between the 28 September 2012, 1600 UTC 294 (corresponding to the start of convective precipitation in the Murcia region) and the 29 September 2952012,0000 UTC.

\subsection{Conditional instability, moisture convergence and low-level jet}

297 As seen in the previous part, the low-level flow over the western Mediterranean on the afternoon of 
298 the 28 September is organized in three main areas: the ahead cold sector on the Balearic Sea and the

299 Gulf of Lion; the warm sector from the Balearic Islands to Murcia and the coasts of North Africa;

300 and the rear cold sector on the Alboran Sea up to Murcia. This organization is well reproduced by

301 the NOWAV simulation with a strong low-level convergence line (Fig. 5a) along the surface cold

302 and occluded fronts. The equivalent potential temperature at the first level of the model (Fig. 5b)

303 shows value above $64^{\circ} \mathrm{C}$ in the warm sector with maximum values above $70^{\circ} \mathrm{C}$ on a large area north

304 of the Algerian coasts. This warm sector is limited by very sharp $\theta_{e}$ gradients: to the south by a low-

305 level rather uniform southerly flow bringing warm and much drier air from the African continent

306 and to the southwest by the cold front with the rear cold sector with equivalent potential

307 temperature below $58^{\circ} \mathrm{C}$. On its north edge, the $\theta_{e}$ gradient corresponding to the warm front is much

308 smoother. However, $\theta_{e}$ decrease to $54^{\circ} \mathrm{C}$ on a large area of the Gulf of Lion and the northern

309 Balearic Sea. Over Spain $\theta_{e}$ is lower, confirming that there is no local feeding or development of

310 convective systems on land away from the coasts (Röhner et al., 2016). The Convective Available

311 Potential Energy (CAPE) at the same time (Fig. 5c) shows values above $1000 \mathrm{~J} \mathrm{~kg}^{-1}$ and up to more

312 than $2000 \mathrm{~J} \mathrm{~kg}^{-1}$ on a large area within the warm sector, ahead of the low-level flow close to the

313 cold front. This high-CAPE area is limited to the north by the ahead cold sector and to the south by

314 the low-level still warm but much drier southerly flow from North Africa. Its southwestern

315 boundary corresponds to the cold front off Murcia at that time, where strong moisture convergence

316 occurs. The Convective Inhibition (CIN, Fig. 5d) is relatively high in the main part of the warm

317 sector, especially north of the North African coast due to the warm and dry southerly flow. By

318 contrast, it shows low values in the westernmost part of the warm sector in the lee of the warm and

319 moist flow. This area at the southwestern edge of the warm sector - with high CAPE and low CIN

320 values - is thus the area the most prone to feed deep convection processes.

321 The simulated radar reflectivities show values above $40 \mathrm{dBz}$ corresponding to convective 
322 precipitation at two different places (Fig. $5 \mathrm{~b}$ to d, green contour): along the occluded front the low323 level moisture convergence above $310^{-5} \mathrm{~kg} \mathrm{~m}^{-3} \mathrm{~s}^{-1}$ (Fig. 5a, green contour); and on land close to 324 Murcia, probably as a result of stationarity of a previous convective system. At sea, the mechanism 325 responsible for the convective precipitation is clearly the strong low-level convergence that remains 326 present along the occluded front and on the triple point between 1500 UTC on 28 September and 3270000 UTC on 29 September.

328 In the ahead cold sector, the $10-\mathrm{m}$ northeasterly wind of 12 to $15 \mathrm{~m} \mathrm{~s}^{-1}$ reinforces to 16 to $32920 \mathrm{~m} \mathrm{~s}^{-1}$ at $500 \mathrm{~m}$ asl (Fig. 5a, 6a). At $1500 \mathrm{~m}$ asl, by contrast, the NOWAV simulated wind field is 330 a more uniform southeasterly flow around $12 \mathrm{~m} \mathrm{~s}^{-1}$ on the ahead cold sector and part of the warm 331 sector (Fig. 6b). The ahead cold sector flow corresponds therefore to a strong low-level jet (LLJ) . 332 Note that this LLJ is clearly visible in the observed and simulated radiosounding profiles in Palma 333 de Mallorca at 1800 UTC and in Barcelona at 1800 UTC and at 0000 UTC (Fig. 4). Oppositely to 334 what has been frequently observed in HPE studies (e.g. Ducrocq et al., 2008), this LLJ is not 335 located in the warm sector corresponding to the conditionally unstable feeding of the convective 336 systems but in a cold sector with $\theta_{e}$ at low level between 48 and $60^{\circ} \mathrm{C}$. It corresponds likely to a 337 low-level jet associated with the low-level pressure gradient ahead of the warm front (e.g. Shapiro 338 and Keyser, 1990).

339 This low-level flow is not saturated in humidity as shown by the surface latent heat flux 340 values up the $500 \mathrm{~W} \mathrm{~m}^{-2}$ on a large area at 1600 UTC on 28 September (Fig. 7a - corresponding 341 relative humidity values between 70 and $80 \%$ ). The ahead cold sector is the only place in the 342 western basin where such values are observed at that time (except very locally under the convective 343 systems, probably in link with wind gusts). This is due to the conjunction of this strong LLJ with 344 dry air masses over the Gulf of Lion and with SST above $23{ }^{\circ} \mathrm{C}$ all over the Balearic Sea as seen in 345 the OSTIA analysis (not shown). By contrast, the SST in the Gulf of Lion is much colder (18 to 
$34620^{\circ} \mathrm{C}$ ) due to an episode of Mistral-Tramontane in the previous days; this results in weak 347 evaporation. As a result of this very strong evaporation on the Balearic Sea, the mixing ratio in the 348 LLJ ranges between 8 and $10 \mathrm{~g} \mathrm{~kg}^{-1}$ over the main evaporative patch (Fig. 7b). It increases 349 gradually when approaching the eastern Spanish coasts, up to $13 \mathrm{~g} \mathrm{~kg}^{-1}$ (see also Fig. S1 and S2 in 350 the Supporting Information). This rising of humidity from $8 \mathrm{~g} \mathrm{~kg}^{-1}$ to more than $12 \mathrm{~g} \mathrm{~kg}^{-1}$ was 351 already seen along backward trajectories in the study of Röhner et al. (2016). These air masses 352 coming from the Gulf of Lion have potential temperatures between 18 and $20^{\circ} \mathrm{C}$. They warm up 353 slightly over the northern Balearic Sea thanks to the strong turbulent heat transfer and approach the 354 Spanish coasts with potential temperature close to $23^{\circ} \mathrm{C}$ (see Fig. S1 and S2).

355 Cold and relatively dry air masses originating from the Gulf of Lion are transported by the 356 LLJ to the Spanish coasts close to Valencia. They moisten and get slightly warmer due to turbulent 357 exchanges with a warmer sea over the Balearic Sea.

\section{$358 \quad 5.2$ Initiation and maintenance processes}

359 We now investigate in more details the processes responsible for the initiation and maintenance of 360 the deep convection in the Murcia-Valencia region, between 1600 and 2300 UTC on 28 September. 361 At this time period, various processes leading to heavy precipitation interact and compete with each 362 other.

The virtual potential temperature $\left(\theta_{v}\right)$ is directly related to the density of air masses and 364 commonly used as a proxy for cold pools (e. g. Ducrocq et al., 2008; Bresson et al., 2012). In the 365 following, we use $\theta_{v}$ values under $23^{\circ} \mathrm{C}$ to identify cold pools, in addition to $\theta_{e}$ characterizing the 366 heat and moisture content of the inflow.

367 At $1600 \mathrm{UTC}$, low values of $\theta_{v}$ are associated with the LLJ in the western part of the Balearic 368 Sea. They correspond to the cold and moist air masses transported from the Gulf of Lion by the 
369 LLJ, as previously described. These air masses are sufficiently cold to make them dense in spite of 370 their moisture and they accumulate on the foothills of the relief at the latitude of Valencia (Fig. 8a).

371 The role of this LLJ in initiation of the cold pool on the coast is confirmed on the vertical cross 372 section along this LLJ (Fig. 8c). Dense air masses with low $\theta_{v}$ are present up to $600 \mathrm{~m}$ asl and 373 transported by this 15 -to- $18 \mathrm{~m} \mathrm{~s}^{-1}$ flow towards the coast. Convective precipitation with 374 instantaneous rates above $20 \mathrm{~mm} \mathrm{~h}^{-1}$ are present southwest of Xabia on land and offshore (Fig. 8b). 375 They correspond to strong vertical velocities at $500 \mathrm{~m}$ above ground level (agl) (Fig. 8a, white 376 contour) and moisture convergence rates above $310^{-5} \mathrm{~kg} \mathrm{~m}^{-3} \mathrm{~s}^{-1}$ at the surface (Fig. 8b, blue 377 contour). Strong convergence at sea is thus the mechanism initiating the convection at that time, 378 with both the LLJ in the ahead cold sector and the weaker flow in the warm sector contributing to 379 the moisture feeding. South of Valencia, along the 2D profile (Fig. 8c) strong convective 380 precipitation correspond to strong vertical velocities (white and black contours) and are located 381 close to the maximum of the topography. The horizontal convergence on the relief slope (vertical 382 blue arrows, Fig. 8c) is the mechanism responsible for the uplift and the corresponding deep 383 convection at that place and time.

384 At 1830 UTC (Fig. 9), the warm and cold fronts bounding the conditionally unstable air mass 385 have moved northeastwards. On the southernmost part of the area, the limit of the convective 386 precipitation with instantaneous rates above $20 \mathrm{~mm} \mathrm{~h}^{-1}$ matches exactly the northern edge of the 387 cold pool (north of Murcia) which is also accurately collocated with strong uplift (Fig. 9a, white 388 contour) and strong moisture convergence rates (Fig. 9b, blue contour). At sea, convective 389 precipitation patches are located on the cold and occluded fronts, and corresponds also to strong 390 convergence rates (Fig. 9b, blue contour). Along the coasts south of Valencia, very high 391 instantaneous rain rates $\left(50 \mathrm{~mm} \mathrm{~h}^{-1}\right)$ are obtained over the sea not associated with high convergence 392 rates (Fig. 9b, 9c). However, their contour (see the instantaneous rates above $20 \mathrm{~mm} \mathrm{~h}^{-1}$ on Fig. 9b) 
393 matches the cold pool present along the coast at the latitude of Valencia, which is the result of both

394 moisture feeding by the northeast LLJ and rain evaporation. Vertical cross sections exhibit two 395 different mechanisms contributing to initiating the deep convection by uplift of the air masses. On 396 the relief as precedently, strong uplift with vertical velocities above $5 \mathrm{~m} \mathrm{~s}^{-1}$ is obtained, resulting in 397 instantaneous rain rate of $50 \mathrm{~mm} \mathrm{~h}^{-1}$. Over the sea, close to the edge of the cold pool which has 398 developed since 1600 UTC, vertical velocities above $1 \mathrm{~m} \mathrm{~s}^{-1}$ above $1500 \mathrm{~m}$ agl (white contour, Fig. 399 9c) result in deep convection. The horizontal convergence (blue vertical arrows, Fig. 9c) is strong at 400 the edge of the cold pool. As no convective cells are present at that place yet, the cold pool is very 401 likely at the origin of the uplift here. On the cold pool itself, strong uplift (white contour) and strong 402 convergence (blue arrows) are collocated with downdraughts with $\theta_{e}$ below $52{ }^{\circ} \mathrm{C}$ and subsidence 403 below $-1 \mathrm{~m} \mathrm{~s}^{-1}$ (black contour), and strong precipitation. At this place, the active convective cells 404 and strong precipitation seem to maintain (and enhance) the cold pool.

405 At 2000 UTC, the main convergence zone along the occluded front is now located south of 406 Valencia (Fig. 10a). The two areas of strong convective precipitation are still present on the relief, 407 northwest of Xabia and south of Valencia. They are collocated with strong convergence rates (Fig. 408 10a, white contour; Fig. 10b, blue contour) and high evaporation at low level on the relief and on 409 the cold pool (not shown). Conversely, at sea off Valencia, strong precipitation rates are not 410 collocated with strong moisture convergence (Fig. 10b), they rather correspond to the coldest patch 411 of the cold pool at sea (Fig. 10a). The surface covered by the cold pool over the sea has slightly 412 increased and the minimum $\theta_{v}$ on land has decreased down to $17^{\circ} \mathrm{C}$. Strong uplifts (white contour, 413 Fig. 10c) collocated with strong horizontal convergence (blue arrows, Fig. 10c) and strong 414 precipitation (Fig. 10b) are located at the edge of the cold pool. Convergence and uplift at the edge 415 of the cold pool are the processes resulting in deep convection here. The already active convection 416 on the relief generates downdraughts (black contour, Fig. 10c) that in turn contribute to the 
417 maintenance of this cold pool on the relief foothills and at sea. On these cold pools at the latitude of

418 Valencia, a deflection of the low-level wind from east-north-east to north-north-east corresponds to

419 the initiation of a barrier wind (Fig. 10a, insert). Barrier winds have been observed and modelled in

420 previous studies, mostly around the Adriatic Sea (Di Muzio, 2014, Davolio et al., 2016). The

421 altitude of the montainous area around Valencia makes it comparable to what is obtained by Di

422 Muzio (2014) with a medium-height orography.

423 At 2130 UTC, the surface covered by the cold pools has further extended at sea, in particular

424 off Xabia (Fig. 11a) and the main moisture convergence zone has reached the latitude of Valencia

425 (Fig. 11b, blue contour, Fig. 11c). The very strong convergence zone offshore is still present with

426 high precipitation rates (see Fig. 11c, blue arrows) in collocation with modelled uplift and

427 downdraughts. On the relief at the latitude of Valencia, high precipitation rates are also collocated

428 with the strong convergence line that progresses northwards with the precipitation patterns.

429 Between these two areas, large patches of very strong precipitation (instantaneous rain rate up to

$430130 \mathrm{~mm} \mathrm{~h}^{-1}$, Fig. 11c) are obtained along the coast, at the latitude of Valencia, in very good

431 collocation with the cold pool extending at sea. Clearly, low-level convergence (blue arrows Fig.

432 11c) is the mechanism responsible for the uplift triggering the deep convection here. It is however

433 difficult to attribute this convergence to the cold pools effect only, as convective cells are already

434 present here. A secondary cyclonic circulation has formed at low level (Fig. 11a, insert), due to the

435 deflection of the low-level wind by the cold-pool edge. It results in shifting the eastern edge of the

436 cold pool southeastwards, and the patches of strong moisture convergence northwards (Fig. 11b).

437 This low-level secondary circulation has already been observed on HPEs (Berthou et al., 2016;

438 Duffourg et al., 2016) as a result of a barrier wind formation. It corresponds here to the minimum of

439 sea-level pressure (see Fig. 12a) and results in a slight bending of the convergence zone at sea. In

440 order to check whether these instantaneous high rain-rates at sea are also present in the 
441 observations, the radar reflectivities obtained in the NOWAV simulation at 2100 UTC are compared

442 with the corresponding observations from the OPERA radar reflectivity Odyssey composite (Fig.

44313 ; the Odyssey product is not available at $2130 \mathrm{UTC}$; http://www.knmi.nl/opera/). The rain

444 amounts are comparable between observations and simulation outputs, and the bending of the

445 convection patterns due to the cold pool and associated to the secondary cyclonic circulation in the

446 NOWAV simulation is also present in the observations.

447 The mechanisms at the origin of heavy precipitation in the Murcia-Valencia region involve 448 orographic forcing on the coastal mountainous range, very strong moisture low-level convergence 449 at sea along the cold front and lifting of the moist LLJ by cold pools that developed on the relief 450 foothills and propagated offshore. These cold pools induce a northerly-to-northwesterly weak 451 barrier wind along the coast, and the setup of a low-level secondary cyclonic circulation resulting in 452 the bending of the convective patterns. These processes play a key role in the location and 453 distribution of heavy precipitation (rainfall cumulative amount above $140 \mathrm{~mm}$ in 6 hours) in the 454 Valencia region. In particular, they explain the rainfall patterns at sea as observed in the radar 455 reflectivity images (Fig. 13).

\section{6. Impact of wave representation}

457 In this part, we discuss the impact of representing explicitly the waves in the WW3_F simulation 458 through the forcing of the Meso-NH model at the surface using the 3-h Wavewatch III® analyses.

459 The objective here is to test the sensitivity of the atmospheric response to the representation of the 460 surface roughness. As shown by Thévenot et al. (2016) on another HPE case study, representing the 461 surface roughness variability due to the wind sea can result in a slowing down of the low-level wind 462 and in a shift of the precipitation place. As shown by the scores of the WW3_F simulation, which 463 are not significantly different from those of NOWAV (Table 1), the overall representation of the 
464 high precipitation is comparable in both simulations.

465

466

467

\subsection{Instantaneous effect on the low-level flow}

We first examine the wave parameters as simulated by the Wavewatch III ${ }^{\circledR}$ model at 1500 UTC on 28 September, and their instantaneous impact on the oceanic and atmospheric surface parameters. The simulated significant wave heights are the largest (more than $2.5 \mathrm{~m}$ ) on the Balearic Sea and south of the Balearic Islands along the coasts of Spain, between Murcia and Xabia (Fig. 14a). The resulting surface roughness difference as parameterized in COARE 3.0 depends mainly on the 10-m wind speed at sea and on the state of development of the wind sea (represented by the significant wave height). This difference is then the biggest in the ahead cold sector, where both strong winds at $10 \mathrm{~m}$ (Fig. 5a) and waves in equilibrium with the wind (Fig. 14a) are present. Roughness length differences are above $510^{-4} \mathrm{~m}$ over a large area (Fig. 14b), which result in a difference on the drag coefficient $C_{d}$ of $0.210^{-3}$ over the whole ahead cold sector (Fig. 14c). Local strong increase of the roughness length (up to $810^{-3} \mathrm{~m}$ ) and of the drag coefficient is also observed more locally under the convective systems and in the rear cold sector. These general increases over the ahead cold sector result in a slowing down of the $10-\mathrm{m}$ wind of more than $0.5 \mathrm{~m} \mathrm{~s}^{-1}$ over a very large area of the ahead cold sector (Fig. 14d). The part of the rear cold sector close to the front shows slowing down of the same magnitude and local patches of wind slowing down by more than $5 \mathrm{~m} \mathrm{~s}^{-1}$ are also observed under the convective systems, collocated with the surface roughness increase. These patches concern very limited areas and are collocated with strong wind and gusts under the convective clouds.

This instantaneous impact of the waves on the low-level flow is different from what has been obtained on another case study (IOP16a) using the same methodology (Thévenot et al., 2016) by two aspects. Firstly, the wind slowing down is weaker than what was obtained by these authors 
487 in average $\left(0.5 \mathrm{~m} \mathrm{~s}^{-1}\right.$ to be compared to $\left.3 \mathrm{~m} \mathrm{~s}^{-1}\right)$, but concerns a larger area. Secondly, this slowing 488 down concerns the two cold sectors, especially the ahead cold sector that contribute to the cold pool 489 initiation and maintenance, but does not impact the warm sector and the feeding of the convective 490 systems by conditionally unstable air masses.

In atmospheric and oceanic surface conditions corresponding to HPEs, the turbulent heat 492 transfer over the sea is generally dominated by the latent heat flux. This is the case here, with strong 493 evaporative fluxes in a large area of the ahead cold sector (see Fig. 7a) between 1500 and 4941900 UTC, as well as locally in the rear cold sector. The differences on the latent heat flux due to 495 the wave representation in the surface forcing of the model are however very weak: $5 \mathrm{~W} \mathrm{~m}^{-2}$ 496 increase on average with mean values of the latent heat flux close to $200 \mathrm{~W} \mathrm{~m}^{-2}$ in the two cold 497 sectors of this simulation. The effect on the low-level air masses participating in the feeding of the 498 systems ( $\theta_{e}$, mixing ratio) is consequently not significant. As in the study of Thévenot et al. (2016), 499 the mechanisms responsible for a possible change in the deep convection and associated heavy 500 precipitation are to be found more likely in dynamical effects of the low-level flow than in the 501 thermal exchanges.

\subsection{Impact on the precipitation field}

503 We now compare the equivalent and virtual potential temperature fields at the first level of the 504 model, at 2130 UTC in the region of Murcia-Valencia, in order to investigate the impact of the wave 505 representation on the convective systems and precipitation. Few differences are observed in the 506 low-level flow feeding the systems itself (Fig. 12; see also Fig. S3 in Supporting Information). The 507 main differences concern the cold pools that extend further east at sea in the WW3_F simulation, 508 especially at the latitude of Valencia. They also show colder $\theta_{v}$ on the coast north of Valencia. As a 509 consequence of this cold pool shift, the precipitation field above $5 \mathrm{~mm} \mathrm{~h}^{-1}$ (instantaneous rain rate; 
510 see yellow contour in Fig. S3) is displaced eastwards. In every simulation, the patterns 511 corresponding to $5 \mathrm{~mm} \mathrm{~h}^{-1}$ rain rate closely follow the edge of the cold pools (corresponding to $\theta_{v}$ 512 under $23^{\circ} \mathrm{C}$ ). This is due to the displacement of the moisture convergence line at the surface on the 513 edge of the cold pool (Fig. 12).

5152130 UTC in the NOWAV simulation (section 5.2, Fig. 11a and 12a), is weakened and displaced at 516 sea in the WW3_F simulation (Fig. 12b). In both simulation outputs, the 10-m wind field is 517 deflected and bended by the cold pool edge, resulting in the WW3_F simulation in a shift of this 518 cyclonic circulation $30 \mathrm{~km}$ eastwards. The sea-level pressure field at 2130 UTC on 28 September 5192012 in the reference simulation NOWAV shows two minima close to $1000 \mathrm{hPa}$ at the latitude of 520 Valencia, corresponding to the well-organized secondary low-level circulation (Fig. 12a). In the 521 WW3_F simulation, higher sea-level pressures up to $1012 \mathrm{hPa}$ are observed near the coast, and the 522 sea-level pressure minimum of $1001 \mathrm{hPa}$ is displaced $30 \mathrm{~km}$ towards Ibiza, out of the cold pool 523 (Fig. 12b). This weakening of the local sea-level pressure minimum has been observed in previous 524 sensitivity studies and can be explained by the slowing down of the low-level wind in WW3_F. 525 Relative higher pressures result, in turn, in an anticyclonic shift of the surface wind and of the 526 displacement of the cyclonic circulation towards sea (Berthou et al., 2016). A weak barrier wind 527 effect is also observed on the cold pools in both simulation.

528 As a result, the precipitation cumulated over $6 \mathrm{~h}$ from $1800 \mathrm{UTC}$ on 28 September to 5290000 UTC on 29 September 2012 show a significant difference in both their amount and their 530 location between WW3_F and NOWAV (Fig. 15). Taking into account the wave effect on the 531 surface roughness results in rain amount more distributed along an east-west profile (Fig. 15b). The 532 peak of precipitation on this 6-h time period over the whole simulation domain reaches $159 \mathrm{~mm}$ in 533 the WW3_F simulation with respect to $258 \mathrm{~mm}$ in the NOWAV simulation. The total amount on the 
534 Valencia area is the same in both simulations with an average of $2.05 \mathrm{~mm} \mathrm{~km}^{-2}$. As seen in Figure $53515 \mathrm{a}$, the precipitation pattern in the WW3_F simulation results is displaced of $50 \mathrm{~km}$ towards sea. 536 Note however that this displacement concern precipitation located mainly at sea and does not affect 537 the forecast scores (Table 1) since they were computed using raingauges observations.

538 This impact of a weakening of the low-level wind field of less than $1 \mathrm{~m} \mathrm{~s}^{-1}$ due to wave 539 representation on the formation and maintenance of cold pools in the coastal domain can be 540 explained by the results of previous studies. Cold pools are known to develop more easily and over 541 larger areas with slower low-level winds (Bresson et al., 2012; Davolio et al., 2016). Lower wind 542 speeds results in more time for the convective cells to develop and for the cold pools to strengthen 543 themselves from evaporating precipitation (Bresson et al., 2012). This relatively low but uniform 544 weakening of the low-level wind induces a significant change on the cold pool extent and location, 545 resulting in a corresponding displacement of the heavy precipitation patterns.

\section{7. Summary and conclusion}

547 This study is part of the HyMeX programme, the objectives of which include a better understanding 548 of the mechanisms triggering the deep convection responsible for heavy precipitation, and the role 549 of the air-sea exchanges in the case of Mediterranean HPEs. In the framework of this programme, 550 the SOP1 IOP8 has been the subject of several studies, either using high-resolution simulations for 551 describing the main mechanisms responsible for deep convection (Röhner et al., 2016), or using 552 observations for a general description of the event (Khodayar et al., 2016). These authors do not 553 provide a detailed study neither of the different mechanisms responsible for uplifting the air masses 554 in a coastal area, leading to strong precipitation, nor of the role of the sea surface exchanges in the 555 event.

556 Here, we focused on the local processes leading to heavy precipitation in the Murcia- 
557 Valencia region between 1600 and 2300 UTC on the 28 September 2012, on their interaction, and 558 on the role of the sea state representation in a model. The use of the non-hydrostatic, convection559 permitting model Meso-NH without and with a more realistic representation of the sea surface 560 roughness provides very accurate representation of the low-level flows and atmospheric stability 561 patterns. In particular, the precipitation amounts, distribution and chronology from 1200 UTC on 28 562 September to 0000 UTC on 29 September are well reproduced by both simulations. The 563 precipitation scores of the reference simulation computed with different thresholds give also 564 excellent results. We then consider these reference simulation outputs suitable for investigating the 565 mechanisms at the origin of this HPE with maximum cumulative rain amount above $200 \mathrm{~mm}$ in $56624 \mathrm{~h}$.

Several mechanisms represented in the simulation outputs have been described in previous 568 studies on the same HPE (Röhner et al., 2016; Khodayar et al., 2016). For instance, the warm and 569 cold sector associated play a role in the moisture and heat feeding of the system when it moves 570 northwards along the Mediterranean Spanish coast from Gibraltar to Catalonia. Low-level 571 conditionally unstable air masses with very high CAPE and low CIN reach eastern Spain in a 572 easterly weak-to-moderate flow. The two main mechanisms mentioned in previous studies, 573 responsible for the lifting of these air masses and leading to the triggering of the deep convection 574 namely orographic forcing on land and strong low-level moisture convergence at sea - were 575 assessed in our reference simulation. The present study reveals other mechanisms at the origin of 576 the deep convection and heavy precipitation (see Fig. 16 for a synthetic scheme). The LLJ is 577 observed here in the ahead cold sector rather than in the main warm low-level fuelling the MCS. It 578 originates in the Gulf of Lion and transports very cold air masses, which barely warm up over the 579 warmer surface waters of the Balearic Sea. These cold thus dense air masses contribute to initiate 580 cold pools on the relief foothills close to the sea. Rain evaporation in the subsaturated mid-level 
581 layer results in downdraughts further developing and maintaining these cold pools. They eventually

582 act as triggering mechanisms of the deep convection when the air masses at their leading edge are

583 thick and dense enough to uplift the incoming conditionally unstable air masses. A weak barrier

584 wind develops from 2000 UTC on 28 September at low level over the cold pool at sea, leading to a

585 cyclonic deflection of the incoming low-level flow (Fig. 11a). A secondary cyclonic circulation

586 results in a bending of the cold pool edge, and in a deflection of the strong low-level convergence

587 zones at sea and of the corresponding convective precipitation. Cold pools play here a key role in

588 the localization of the deep convection and associated heavy precipitation at sea off Valencia rather

589 than on the relief foothills.

590 Representing in a more realistic way the sea state using the 3-hourly Wavewatch III ${ }^{\circledR}$ 591 analyses as a forcing has a significant impact on the simulation results. It first increases the surface 592 roughness, resulting in an increase of the wind stress, thus in a slight decrease of the low-level 593 wind. The main conditionally unstable low-level flow feeding the convective systems in warm and 594 moist air is not impacted, but the moderate wind slowing down over a large part of the secondary 595 flow in the ahead cold sector (low-level jet) is sufficient to affect significantly the location of the 596 heavy precipitation at sea in the Valencia region. The cold pools are displaced further at sea, 597 strengthened, and shift accordingly the place of strong convergence and convective precipitation. 598 The sea-level pressure field is changed towards higher pressures and the low-level wind field is 599 modified accordingly by an anticyclonic shift.

600 Conversely, no impact of the wind sea on the heat exchanges at the sea surface has been 601 observed in this study. The mean change of the latent heat flux of $5 \mathrm{~W} \mathrm{~m}^{-2}$ over the Balearic Sea 602 does not change significantly the moisture content or equivalent potential temperature in the LLJ 603 feeding the convective systems. This reinforces the similar results obtained in a previous study on 604 the HyMeX SOP1 IOP16a (Thévenot et al., 2016). Either developed wind sea concerns the area of 
605 warm and moist air directly feeding the HPE, as this was the case in IOP16a, and the low-level flow 606 is already saturated in humidity; as a result, the latent heat transfer change due to waves is weak. Or 607 it concerns an area not saturated in humidity yet as this is the case in IOP8, and this flow plays only 608 a secondary role in the HPE. This shows that the effect of the sea state on the heat exchanges in 609 systems leading to HPEs is likely very small.

610 This study of the sensitivity to wave impact uses an atmospheric model at high resolution 611 forced by realistic modelled sea states. The conclusion of this part of our study would probably be 612 different if the simulation was carried out using a full coupling between the atmospheric and the 613 wave model.

\section{Acknowledgements}

615 The authors acknowledge Météo-France and the HyMeX programme for supplying the data, 616 sponsored by Grants MISTRALS/HyMeX and ANR-11-BS56-0005 IODA-MED project. The 617 authors thank the HyMeX database teams (ESPRI/IPSL and SEDOO/Observatoire Midi-Pyrénées) 618 for their help in accessing the data, as well as all SOP1 field teams who performed measurements 619 during this time, the MeteoCat service for performing high-resolution radiosoundings in Barcelona, 620 the AEMET service for performing high-resolution radiosoundings in Murcia, EUMETSAT and 621 SATMOS for supplying the SEVIRI onboard Meteosat Second Generation 2 infrared channel 622 brightness temperature data, and EUMETSAT and the KNMI scatterometer team for providing the 623 ASCAT surface wind images. The authors are also grateful to C. Lac, G. Tanguy and F. Duffourg 624 (Météo-France, CNRM) for their help with the modelling part. The PCIM (Pôle de Calcul Intensif 625 pour la Mer) support team is acknowledged for providing the corresponding computing facility. The 626 authors are also grateful to two anonymous reviewers for improving the quality of this paper.

\section{References}


628 Ardhuin F, Rogers E, Babanin AV, Filipot JF, Magne R, Roland A, Van Der Westhuysen A, 629 Queffeulou P, Lefevre JM, Aouf L, Collard F. 2010. Semiempirical dissipation source 630 functions for ocean waves. Part I: Definition, calibration, and validation. J. Phys. 631 Oceanography, 40(9): 1917-1941, doi:10.1175/2010JPO4324.1.

632 Barthlott C, Kirshbaum DJ. 2013. Sensitivity of deep convection to terrain forcing over 633 Mediterranean islands. Q. J. R. Meteorol. Soc. 139: 1762-1779, doi:10.1002/qj.2089.

634 Berthou S, Mailler S, Drobinski P, Arsouze T, Bastin S, Béranger K, Flaounas E, Lebeaupin 635 Brossier C, Somot S, Stéfanon M. 2016. Influence of submonthly air-sea coupling on heavy 636 precipitation events in the Western Mediterranean basin. Q.J.R. Meteorol. Soc. 142: 453-471, 637 doi:10.1002/qj.2717.

638 Bougeault P, Lacarrère P. 1989. Parameterization of orography-induced turbulence in a meso-beta639 scale model. Mon. Weather Rev. 117: 1872-1890.

640 Bresson E, Ducrocq V, Nuissier O, Ricard D, de Saint-Aubin C. 2012. Idealized numerical study of 641 Southern France heavy precipitating events: Identification of favouring ingredients. Q. J. R. $642 \quad$ Meteorol. Soc. 138: 1751-1763.

643 Buzzi A, Davolio S, Malguzzi P, Drofa O, Mastrangelo D. 2014. Heavy rainfall episodes over 644 Liguria in autumn 2011: numerical forecasting experiments. Nat. Hazards Earth Syt. Sci. 14: 645 1325--1340 doi:10.5194/nhess-14-1325-2014.

646 Caniaux G, Redelsperger JL, Lafore JP. 1994. A numerical study of the stratiform region of a fast647 moving squall line. J. Atmos. Sci. 51: 2046-2074.

648 Cuxart J, Bougeault P, Redelsperger JL. 2000. A turbulence scheme allowing for mesoscale and 649 large-eddy simulations. Q. J. R. Meteorol. Soc. 126: 1-30, doi: 10.1002/qj.49712656202.

650 Davolio S, Volonté A, Manzato A, Pucillo A, Cicogna A, Ferrario ME. 2016. Mechanisms 651 producing different precipitation patterns over north-eastern Italy: insights from HyMeX- 

SOP1 and previous events. Q.J.R. Meteorol. Soc. 142: 188-205, doi:10.1002/qj.2731.

653 654
Di Muzio E. 2014. 'Climatological characterization and dynamics of barrier winds in the Italian region', $\mathrm{PhD}$ thesis. http://amslaurea.unibo.it/6688 (accessed 2 October 2016).

Donlon CJ, Martin M, Stark JD, Roberts-Jones J, Fiedler E, Wimmer W. 2012. The operational sea surface temperature and sea ice analysis (OSTIA) system. Remote Sens. Environ. 116: 140158, doi:10.1016/j.rse.2010.10.0172011.

Drobinski P, Ducrocq V, Alpert P, Anagnostou E, Béranger K, Borga M, Braud I, Chanzy A, Davolio S, Delrieu G, Estournel C, Filali Boubrahmi N, Font J, Grubisic V, Gualdi S, Homar V, Ivanan-Picek B, Kottmeier C, Kotroni V, Lagouvardos K, Lionello P, Llasat MC, Ludwig W, Lutoff C, Mariotti A, Richard E, Romero R, Rotunno R, Roussot O, Ruin I, Somot S, Taupier-Letage I, Tintoré J, Uijlenhoet R, Wernli H. 2014. HyMeX: A 10-year multidisciplinary program on the Mediterranean water cycle. Bull. Am. Meteorol. Soc. 95: 1063-1082, doi:10.1175/BAMS-D-12-00242.1.

Ducrocq V, Nuissier O, Ricard D. 2008. A numerical study of three catastrophic precipitating events over Southern France. Part II: Mesoscale triggering and stationarity factors. Q. J. R. Meteorol. Soc. 134: 131-145, doi:10.1002/qj.199.

Ducrocq V, Braud I, Davolio S, Ferretti R, Flamant C, Jansà A, Kalthoff N, Richard E, TaupierLetage I, Ayral PA, Belamari S, Berne A, Borga M, Boudevillain B, Bock O, Boichard JL, Bouin MN, Bousquet O, Bouvier C, Chiggiato J, Cimini D, Corsmeier U, Coppola L, Cocquerez P, Defer E, Delano J, Di Girolamo P, Doerenbecher A, Drobinski P, Dufournet Y, Fourrié N, Gourley JJ, Labatut L, Lambert D, Le Coz J,Marzano FS, Molinié G, Montani A, Nord G, Nuret M, Ramage K, Rison B, Roussot O, Said F, Schwarzenboeck A, Testor P, Van Baelen J, Vincendon B, Aran M, Tamayo J. 2014. HyMeX-SOP1: The field campaign dedicated to heavy precipitation and flash flooding in the Northwestern Mediterranean. Bull. 

Am. Meteorol. Soc. 95: 1083-1100, doi:10.1175/BAMS-D-12-00244.1.

677 Ducrocq V, Davolio S, Ferretti R, Flamant C, Santaner VH, Kalthoff N, Richar E, Wernli H. 2016. 678 Editorial. Introduction to the HyMeX Special Issue on 'Advances in understanding and 679 forecasting of heavy precipitation in Mediterranean through the HyMeX SOP1 field 680 campaign', Q.J.R. Meteorol. Soc., 142(1): 1-6, doi:10.1002/qj.2856.

681 Duffourg F, Nuissier O, Ducrocq V, Flamant C, Chazette P, Delanoë J, Doerenbecher A, Fourrié N, 682 Di Girolamo P, Lac C, Legain D, Martinet M, Saïd F, Bock O. 2016. Offshore deep 683 convection initiation and maintenance during the HyMeX IOP 16a heavy precipitation event. 684 Q.J.R. Meteorol. Soc. 142: 259-274, doi:10.1002/qj.2725.

685 Fairall CW, Bradley EF, Hare JE, Grachev AA, Edson JB. 2003. Bulk parameterization of air-sea 686 fluxes: Updates and verification for the COARE algorithm. J. Clim. 16: 571-591.

687 Fourrié N, Bresson E, Nuret M, Jany C, Brousseau P, Doerenbecher A, Kreitz M, Nuissier O, 688 Sevault E, Bénichou H, Amodei M, Pouponneau F. 2015. AROME-WMED, a real-time 689 mesoscale model designed for the HyMeX special observation periods. Geosci. Model Dev. 8: 690 1919-1941, doi:10.5194/gmd-8-1919-2015.

691 Gal-Chen T, Somerville RCJ. 1975. On the use of a coordinate transformation for the solution of the 692 Navier-Stokes equations. J. Comput. Phys. 17: 209-228, doi: 10.1016/0021-9991(75) 900376936

694 Hanssen AW, Kuipers WJA. 1965. 'On the relationship between the frequency of rain and various 695 meteorological parameters: with reference to the problem of objective 696 forecasting`.Wageningen UR Library:Wageningen, Holland.

697 Hare JE, Persson POG, Fairall CW, Edson JB. 1999. 'Behavior of Charnock's relationship for high 698 wind conditions', Proc. 13th Symp. on Bound. Layers and Turbulence. American Meteorol. 699 Soc.: Dallas, TX, pp 252-255. 
700 Jansà A, Campins J, Picornell MA, Guijarro JA. 2014. Heavy rain and strong wind events over 701 Spain during HyMeX SOP1. Thetys, Journal of Mediterranean Meteorology and Climatology $702 \quad 11: 25-38$.

703 Khodayar S, Raff F, Kalthoff N, Bock O. 2016. Diagnostic study of a high-precipitation event in the 704 Western Mediterranean: adequacy of current operational networks. Q.J.R. Meteorol. Soc., 705 142: $72-85$, doi:10.1002/qj.2600.

706 Lafore JP, Stein J, Asencio N, Bougeault P, Ducrocq V, Duron J, Fischer C, Héreil P, Mascart P, 707 Masson V, Pinty JP, Redelsperger JL, Richard E, Vilà- Guerau de Arellano J. 1998. The Meso$708 \mathrm{NH}$ atmospheric simulation system. Part I: Adiabatic formulation and control simulations. 709 Ann. Geophys. 16: 90-109, doi: 10.1007/s00585-997-0090-6.

710 Llasat MC, Llasat-Botija M, Petrucci O, Pasqua AA, Rossell J, Vinet F, Boissier L. 2013. Towards a 711 database on societal impact of Mediterranean floods within the framework of the HyMeX 712 project. Nat. Hazards Earth Syst. Sci. 13: 1337-1350, doi: 10.5194/nhess-13-1337-2013.

713 Masson V, Le Moigne P, Martin E, Faroux S, Alias A, Alkama R, Belamari S, Barbu A, Boone A, 714 Bouyssel F, Brousseau P, Brun E, Calvet JC, Carrer D, Decharme B, Delire C, Donier S, 715 Essaouini K, Gibelin AL, Giordani H, Habets F, Jidane M, Kerdraon G, Kourzeneva E, 716 Lafaysse M, Lafont S, Lebeaupin-Brossier C, Lemonsu A, Mahfouf J-F, Marguinaud P, 717 Mokhtari M, Morin S, Pigeon G, Salgado R, Seity Y, Taillefer F, Tanguy G, Tulet P, Vincendon 718 B, Vionnet V, Voldoire A. 2013. The SURFEXv7.2 land and ocean surface platform for 719 coupled or offline simulation of Earth surface variables and fluxes. Geosci. Model Dev. 6: 720 929-960, doi: 10.5194/gmd-6-929-2013.

721 Miglietta M, Rotunno R. 2010. Numerical simulations of low-CAPE flows over a mountain ridge. 722 J. Atmos. Sci. 67: 2391-2401, doi: 10.1175/2010JAS3378.1.

723 Miglietta MM, Rotunno R. 2012. Application of theory to observed cases of orographically forced 
convective rainfall, Mon. Weather Rev. 140: 3039-3053.

725 Nuissier O, Ducrocq V, Ricard D. 2008. A numerical study of three catastrophic precipitating events 726 over Southern France. Part I: Numerical framework and synoptic ingredients. $Q . J . R$. $727 \quad$ Meteorol. Soc. 134: 111-130, doi: 10.1002/qj.200.

728 Nuissier O, Joly B, Joly A, Ducrocq V, Arbogast P. 2011. A statistical downscaling to identify the 729 large-scale circulation patterns associated with heavy precipitation events over Southern $730 \quad$ France. Q. J. R. Meteorol. Soc. 137: 1812-1827, doi: 10.1002/qj.866.

731 Oost WA, Komen GJ, Jacobs CMJ, Van Oort C. 2002. New evidence for a relation between wind 732 stress and wave age from measurements during ASGAMAGE. Boundary-Layer Meteorol. 733 103: 409-438, doi: 10.1023/A:1014913624535.

734 Pinty JP, Jabouille P. 1998. 'A mixed-phased cloud parametrization for use in a mesoscale non735 hydrostatic model: Simulations of a squall line and of orographic precipitation`. In 736 Proceedings of the Conference on Cloud Physics, 17-21 August, Everett, WA: 217-220. 737 American Meteorological Society: Boston.

738 Ricard D, Ducrocq V, Auger L. 2012. A climatology of the mesoscale environment associated with 739 heavily precipitating events over a northwestern Mediterranean area. J. Appl. Meteorol. Clim. $740 \quad$ 51: 468-488, doi: 10.1175/JAMC-D-11-017.1.

741 Röhner L, Nerding KU, Corsmeier U. 2016. Diagnostic study of a HyMeX heavy precipitation 742 event over Spain by investigation of moisture trajectories. Q.J.R. Meteorol. Soc. 142: 287$743 \quad 297$, doi:10.1002/qj.2825.

744 Schaefer JT. 1990. The critical success index as an indicator of warning skill. Weather Forecasting 745 5: 570-575, doi: 10.1175/1520-0434(1990)005.

746 Shapiro, M.A., and D. Keyser, 1990: Fronts, jet streams and the tropopause. Extratropical 747 Cyclones: The Erik Palmen Memorial Volume, C., W. Newton and E. O. Holopainen, Eds., 
748 Amer. Meteor. Soc., 167-191.

749 Taillefer F. 2002. 'CANARI (Code for the Analysis Necessary for Arpege for its Rejects and its 750 Initialization): Technical Documentation', Technical Report. CNRM/GMAP, Groupe de 751 Modél. pour 1'Assimilation et la Prévision, Cent. Nati. de Rech. Météorol., Météo-France, 752 Toulouse, France. http://www.cnrm.meteo.fr/gmapdoc/spip.php?article3 (accessed 2 May 753 2017).

754 Thévenot O, Bouin MN, Ducrocq V, Lebeaupin Brossier C, Nuissier O, Pianezze J, Duffourg F. 755 2016. Influence of the sea state on Mediterranean heavy precipitation: a case-study from 756 HyMeX SOP1. Q.J.R. Meteorol. Soc., 142: 377-389, doi:10.1002/qj.2660.

757 Tolman H. 2014. 'User manual and system documentation of WAVEWATCH III version 4.18'. 758 Environmental Modeling Center Marine Modeling Analysis Branch. 


\section{Mean bias SDD Correlation $r$ ETS HK}

\section{Threshold}

$5 \mathrm{~mm} \quad 15 \mathrm{~mm} \quad 25 \mathrm{~mm} \quad 5 \mathrm{~mm} \quad 15 \mathrm{~mm} \quad 25 \mathrm{~mm}$

NOWAV

$\begin{array}{lll}0.4 & 15.5 & 0.74\end{array}$

0.63

$0.78 \quad 0.64$

0.79

0.90

0.80

\begin{tabular}{llll}
\hline WW3_F & 0.4 & 16.0 & 0.72
\end{tabular}

0.63

0.74

0.61

0.79

0.89

0.79

Table 1: Mean bias, standard deviation difference, ETS and HK scores (see text) of the NOWAV and WW3_F simulations against 24-h accumulated rain gauge observations on 28 September 2012 (mean bias and SDD in mm). 
(a) ARPEGE analysis 28/09/2012 00 UTC

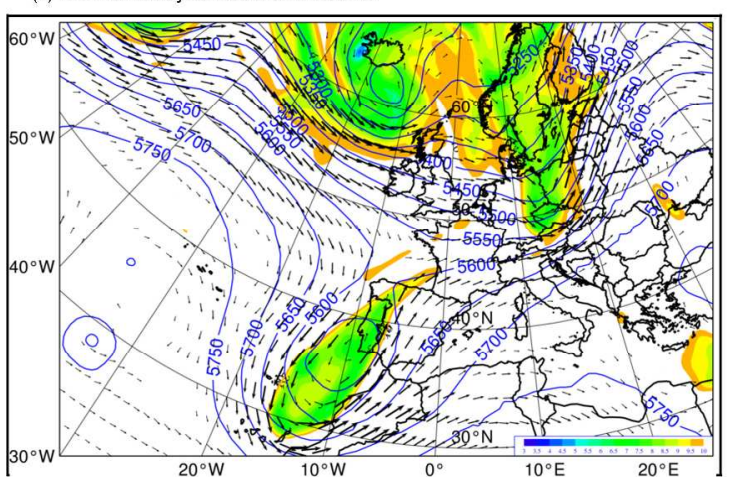

(b) Synoptic chart 28/09/2012 18 UTC

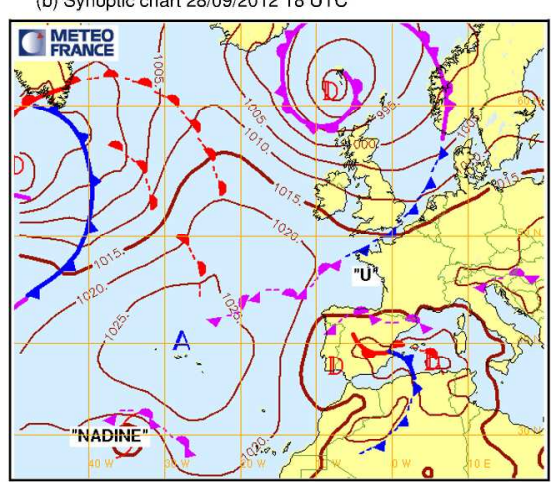

Figure 1: Synoptic conditions of the IOP8 with (a) ARPEGE analysis showing the height of potential vorticity anomaly equal to 2.0 PVU (colour chart, $\mathrm{km}$ ), the $500 \mathrm{hPa}$ geopotential (isobars, $\mathrm{m}$ ) and the $300 \mathrm{hPa}$ wind (above $10 \mathrm{~m} \mathrm{~s}^{-1}$ ) at 0000 UTC on 28 September 2012 and (b) synoptic Meteo-France analysis with fronts and isobars, at 1800 UTC on 28 September 2012.

$273 \times 104 \mathrm{~mm}(300 \times 300 \mathrm{DPI})$ 


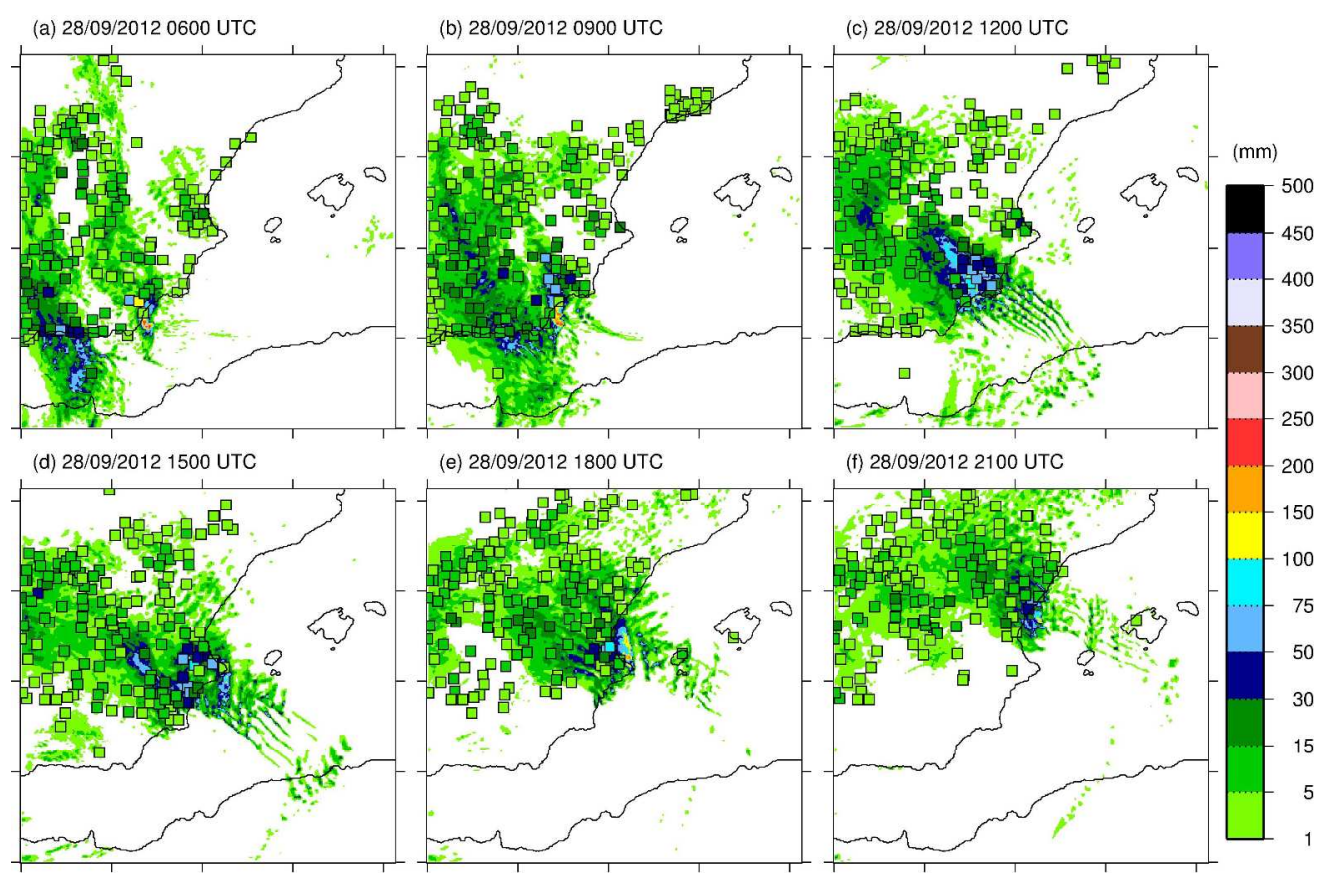

Figure 2: Three-hour cumulated rain amount from the NOWAV simulation (see Table 1 and sections 3.1 and 3.2) and measured by rain gauges (coloured squares) starting at (a) 0600 UTC, (b) 0900 UTC, (c) 1200 UTC, (d) 1500 UTC, (e) 1800 UTC and (f) 2100 UTC on 28 September 2012.

\section{$278 \times 183 \mathrm{~mm}(300 \times 300 \mathrm{DPI})$}


(a) ASCAT surface wind

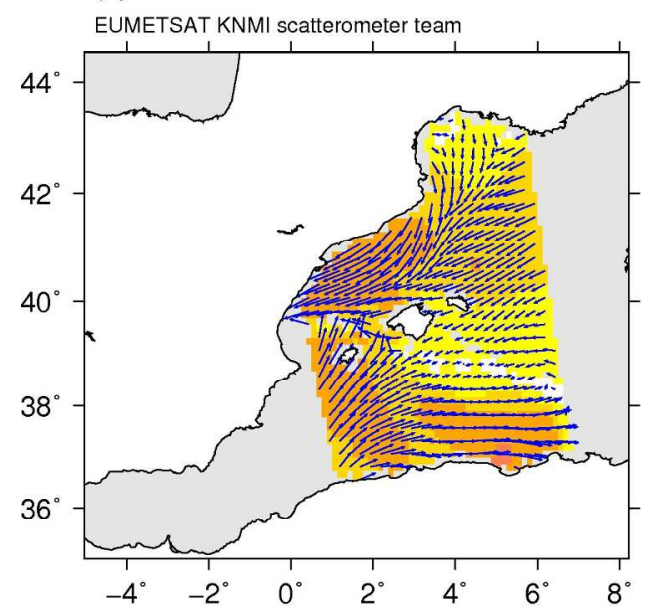

(b) Model surface wind

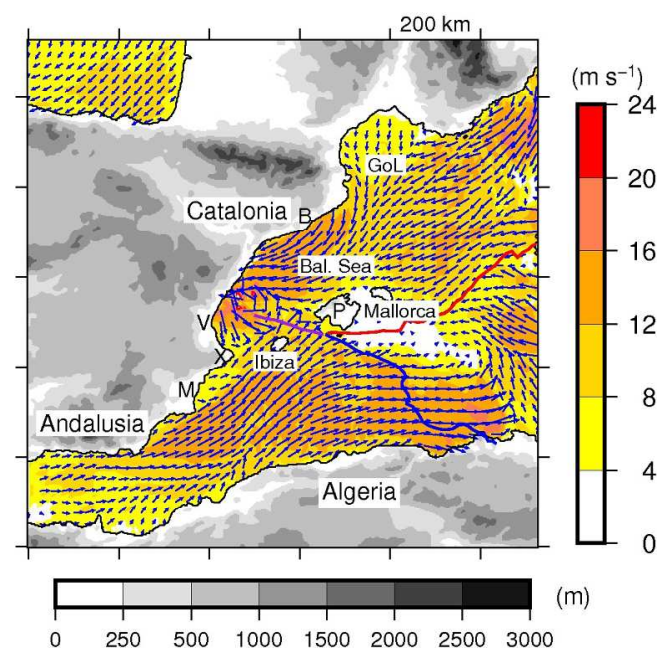

Figure 3: Sea surface wind $\left(\mathrm{m} \mathrm{s}^{-1}\right)$ (a) from ASCAT onboard Metop-A between 2100 UTC on 28 September and 0000 UTC on 29 September and (b) from the NOWAV simulation (see sections 3.1 and 3.2) at 2230 UTC on 28 September 2012, with the surface fronts superimposed. V denotes Valencia, B Barcelona, M Murcia, X Xabia, and P Palma de Mallorca. The topography (grey scale, $\mathrm{m}$ ) and main geographical areas are also indicated (b).

$192 \times 102 \mathrm{~mm}(300 \times 300 \mathrm{DPI})$

32

33

34

35

36

37

38

39

40

41

42

43

44

45

46

47

48

49

50

51

52

53

54

55

56

57

58

59

60 


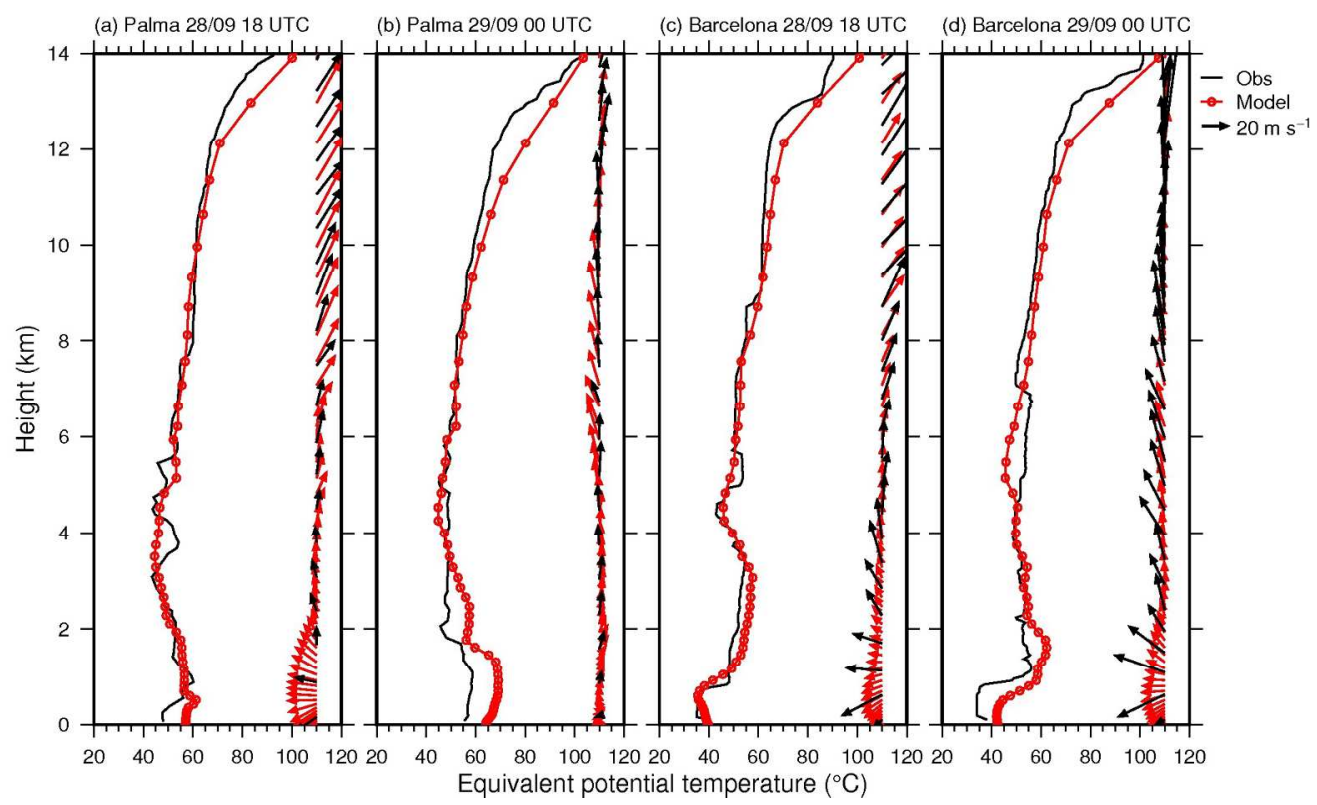

Figure 4: Vertical profiles (height in $\mathrm{km}$ ) of equivalent potential temperature $\left({ }^{\circ} \mathrm{C}\right.$ ) and horizontal wind (vector) from radio soundings (black) and from NOWAV simulation (red) in Palma de Mallorca (a) at 1800 UTC on 28 September 2012 and (b) at 0000 UTC on 29 September, and in Barcelona (c) at 1800 UTC on 28 September and (d) at 0000 UTC on 29 September 2012. 
(a) 10-m wind

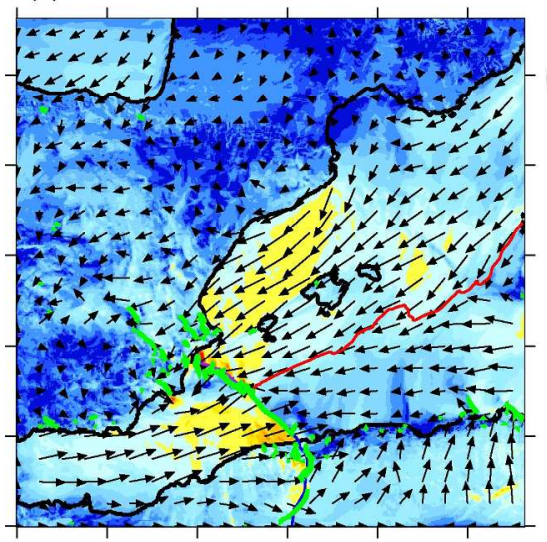

(c) CAPE

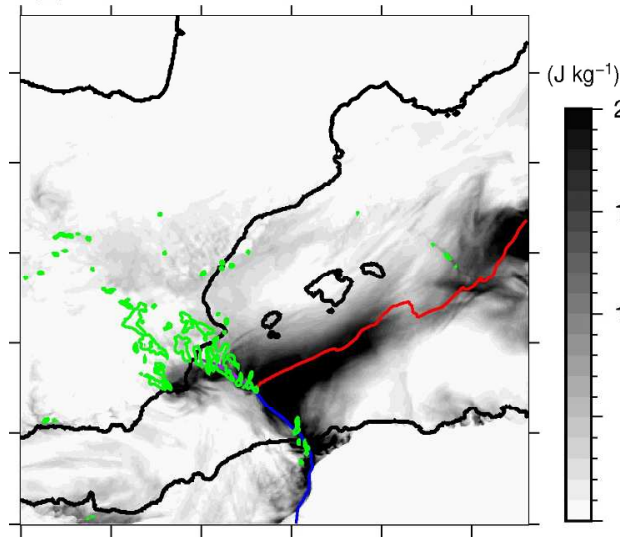

(b) $\theta_{\mathrm{e}}$

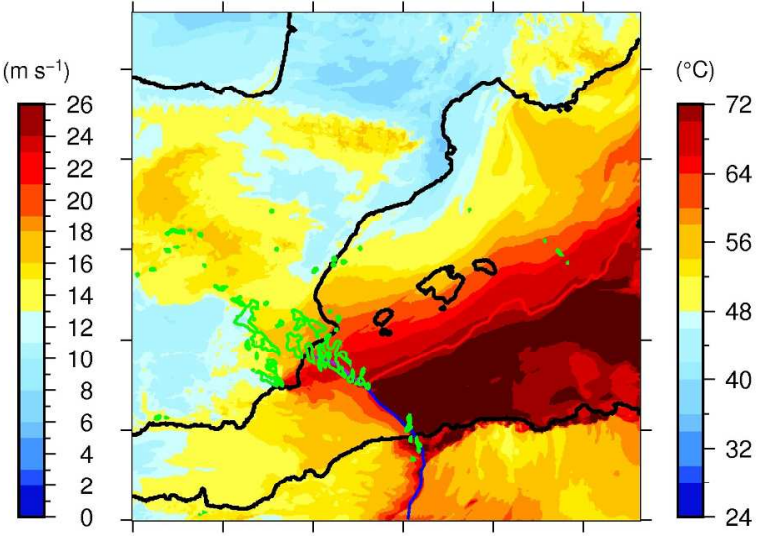

(d) CIN

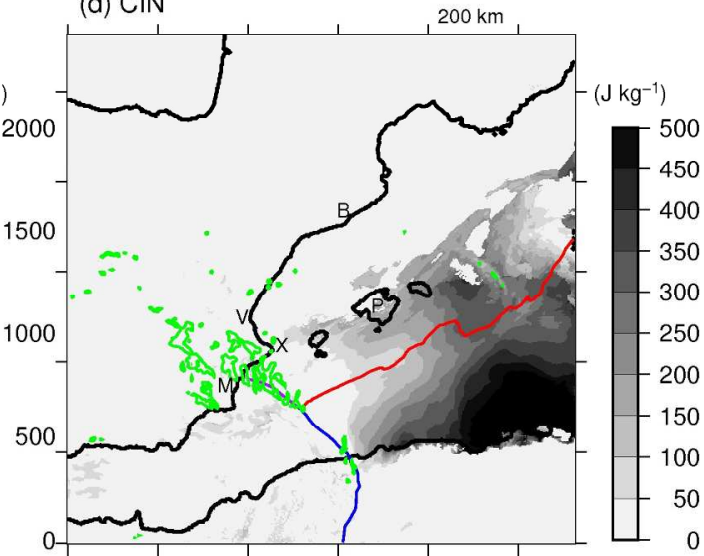

Figure 5: (a) 10-m wind $\left(\mathrm{m} \mathrm{s}^{-1}\right)$, (b) equivalent potential temperature $\left({ }^{\circ} \mathrm{C}\right),(\mathrm{c})$ convective available potential energy $\left(\mathrm{J} \mathrm{kg}^{-1}\right)$, and (d) convective inhibition $\left(\mathrm{J} \mathrm{kg}^{-1}\right)$ from the NOWAV simulation, at 1600 UTC on 28 September 2012. The green contour in (a) indicates the moisture convergence rate above $310^{-5} \mathrm{~kg} \mathrm{~m}^{-3} \mathrm{~s}^{-1}$ at the surface. The green contour in (b), (c), (d) indicates the simulated radar reflectivity at $2000 \mathrm{~m}$ above $40 \mathrm{dBz}$. The red (resp. blue) line indicates the warm (rep. cold) front, the purple line the occluded front. $V$ denotes Valencia, B Barcelona, M Murcia, X Xabia, and P Palma de Mallorca. 
(a) 500-m wind

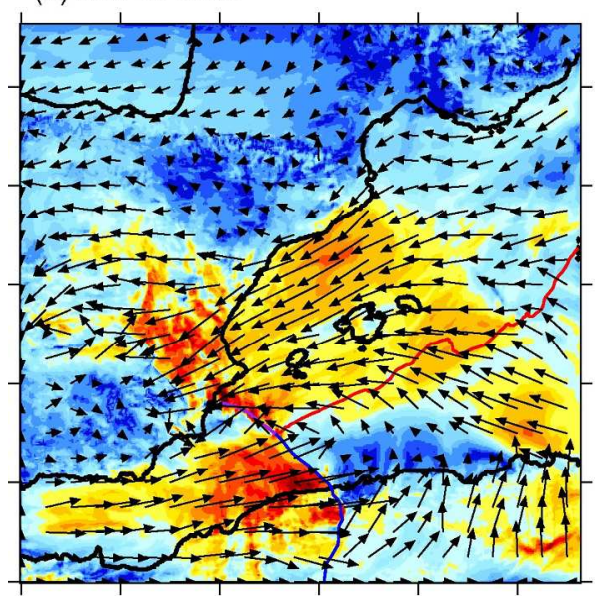

(b) 1500-m wind

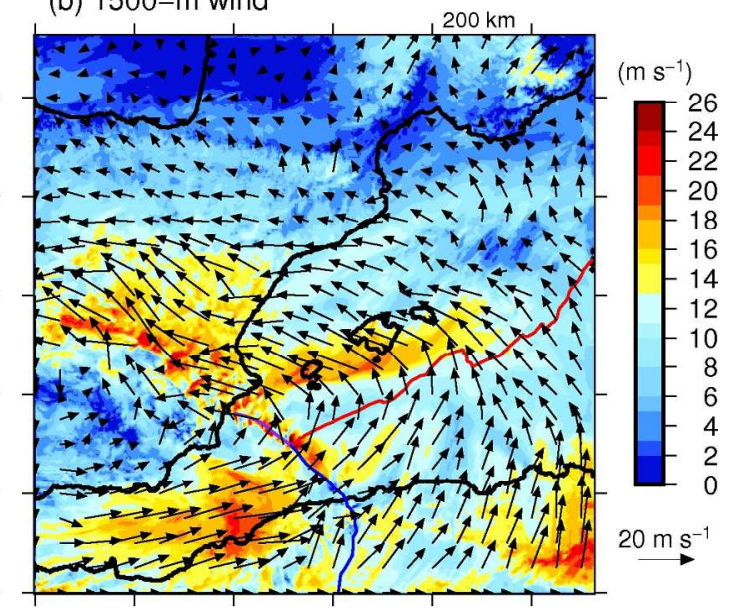

Figure 6: Wind field from the NOWAV simulation $\left(\mathrm{m} \mathrm{s}^{-1}\right)$ at 1600 UTC on 28 September 2012 , (a) at $500 \mathrm{~m}$ and (b) at $1500 \mathrm{~m}$ agl. The red (resp. blue) line indicates the warm (rep. cold) front, the purple line the occluded front.

$186 \times 90 \mathrm{~mm}(300 \times 300$ DPI $)$ 
(a) Latent heat flux

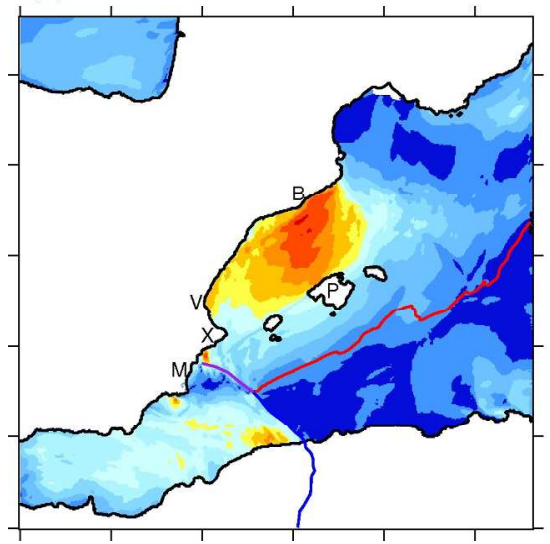

(b) 200-m mixing ratio

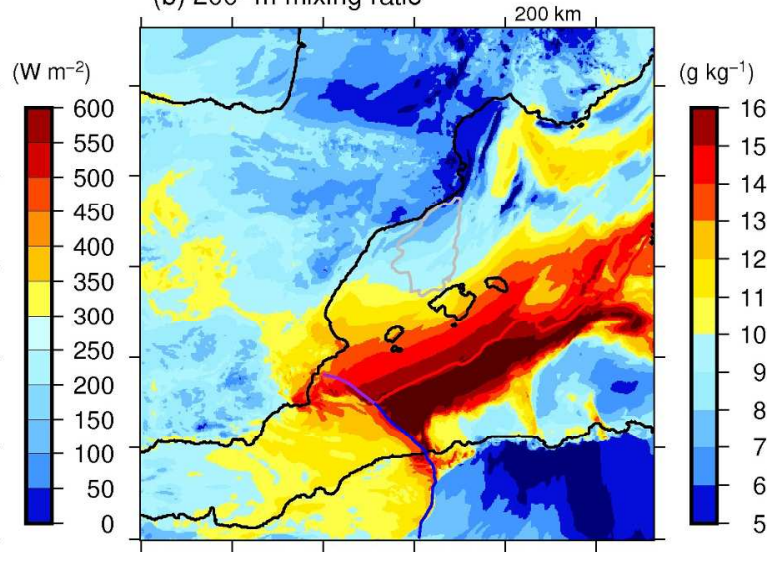

Figure 7: (a) Surface latent heat flux $\left(\mathrm{W} \mathrm{m}^{-2}\right)$ and (b) mixing ratio at $200 \mathrm{~m}\left(\mathrm{~g} \mathrm{~kg}^{-1}\right)$ from the NOWAV simulation at 1600 UTC on 28 September 2012. The grey contour in (b) indicates the area with surface evaporation above $400 \mathrm{~W} \mathrm{~m}^{-2}$. The red (resp. blue) line indicates the warm (rep. cold) front, the purple line the occluded front. V denotes Valencia, B Barcelona, M Murcia, X Xabia, and P Palma de Mallorca. 
(a) Equivalent potential temperature

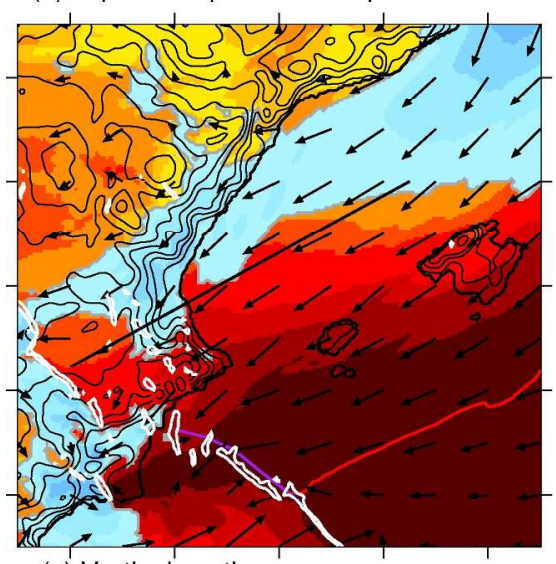

(c) Vertical section

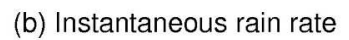

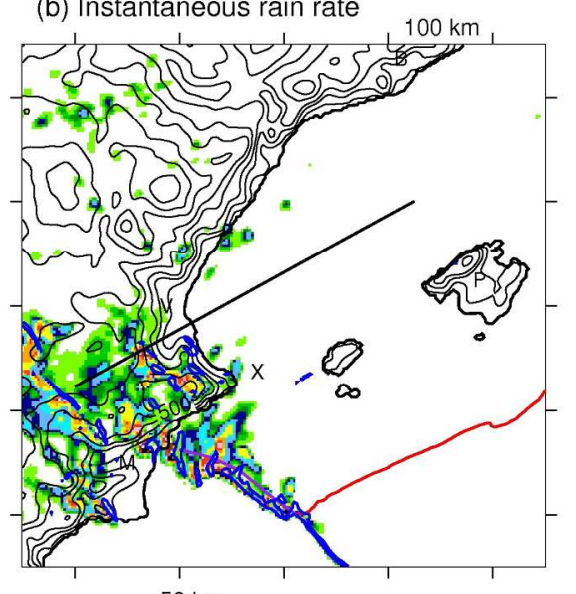

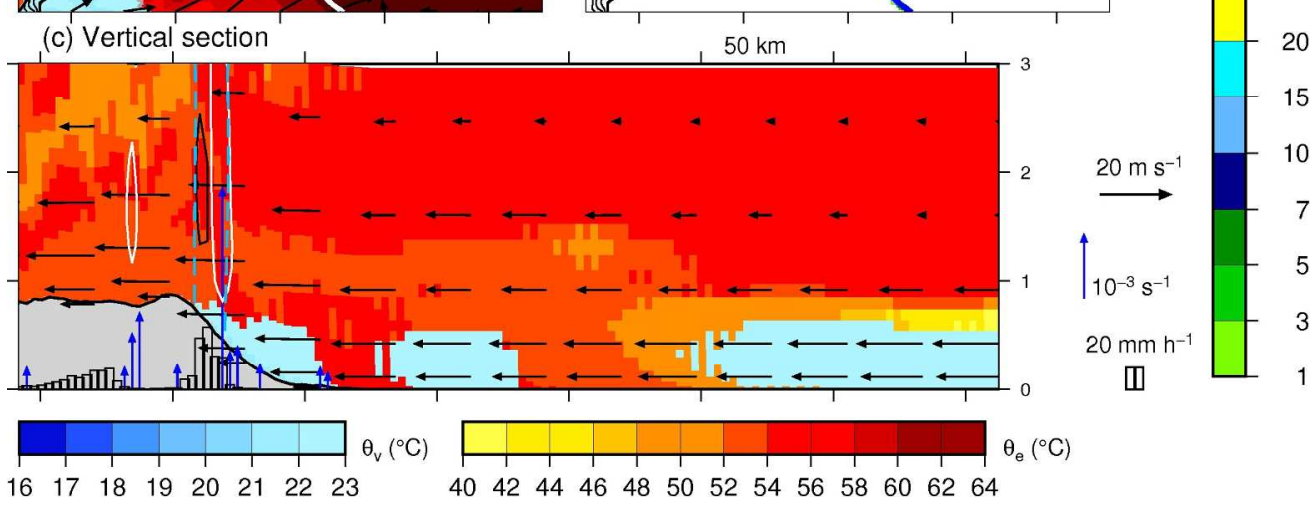

Figure 8: (a) Equivalent potential temperature and virtual potential temperature at the surface $\left({ }^{\circ} \mathrm{C}\right.$, colour scale), $10-\mathrm{m}$ wind (vectors), and vertical velocities above $1 \mathrm{~m} \mathrm{~s}^{-1}$ at $500 \mathrm{~m}$ agl (white contour); (b) Instantaneous rain rate $\left(\mathrm{mm} \mathrm{h}^{-1}\right.$, colour scale), and moisture convergence rate above $310^{-5} \mathrm{~kg} \mathrm{~m}^{-3} \mathrm{~s}^{-1}$ at the surface (blue contour); (c) vertical profiles of the equivalent potential temperature and virtual potential temperature $\left({ }^{\circ} \mathrm{C}\right.$, colour scale ; height scale in $\left.\mathrm{km}\right)$, projection of the wind (black arrows), instantaneous rain rate (vertical bars), vertical velocities above $1 \mathrm{~m} \mathrm{~s}^{-1}$ (white contour) or below $-1 \mathrm{~m} \mathrm{~s}^{-1}$ (black contour), cloud precipitating water above $1 \mathrm{~g} \mathrm{~kg}^{-1}$ (light blue, dashed contour), and horizontal convergence at $120 \mathrm{~m}$ agl (blue arrows) from the NOWAV simulation at 1600 UTC on 28 September 2012. The black line in (a) indicates the vertical cross section used in (c). The virtual potential temperature in (a) and (c) replaces the equivalent potential temperature when under $23^{\circ} \mathrm{C}$ to indicate cold pools. The red (resp. blue) line in (a) and (b) indicates the warm (rep. cold) front, the purple line indicates the occluded front. $V$ denotes Valencia, B Barcelona, M Murcia, X Xabia, and P Palma de Mallorca. 
(a) Equivalent potential temperature

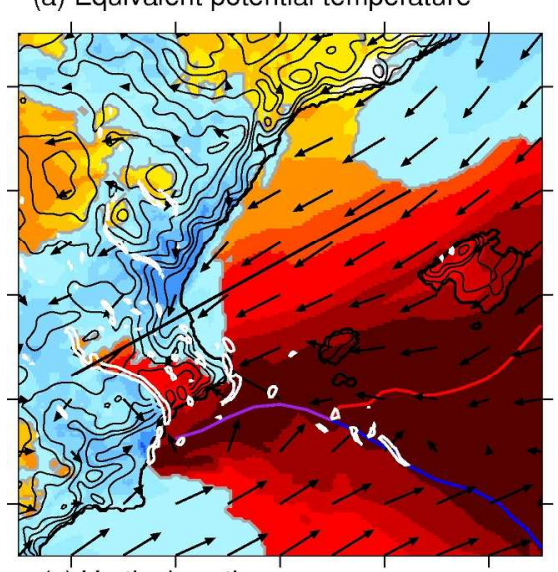

(c) Vertical section (b) Instantaneous rain rate

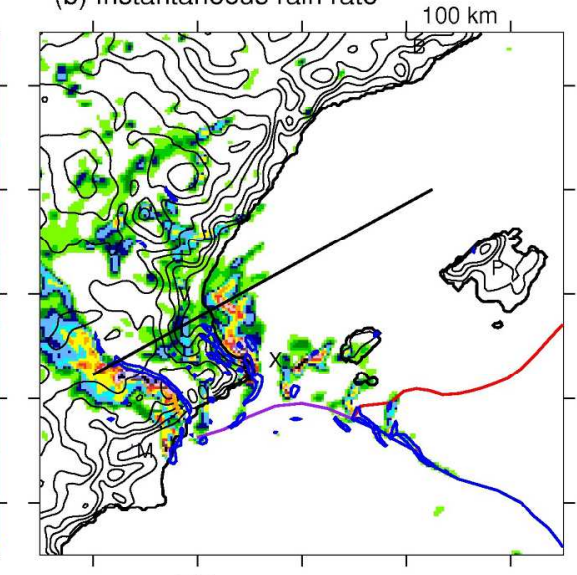

$50 \mathrm{~km}$
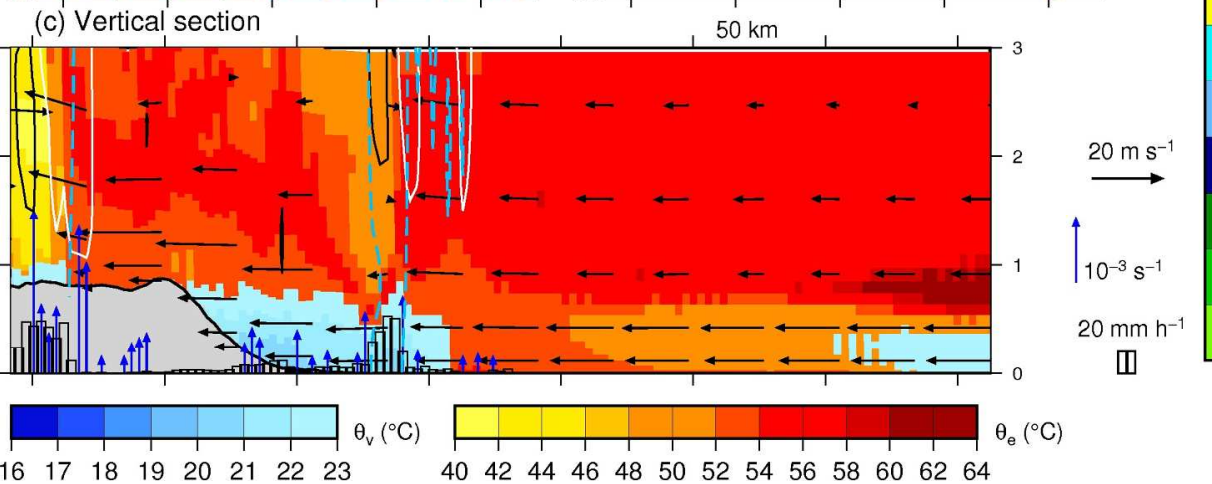

$\left(\mathrm{mm} \mathrm{h}^{-1}\right)$

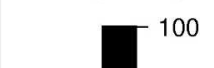

90

80

70

60

50

40

Figure 9: Same as Figure 8, but at 1830 UTC on 28 September 2012.

$199 \times 163 \mathrm{~mm}(300 \times 300$ DPI $)$ 
(a) Equivalent potential temperature

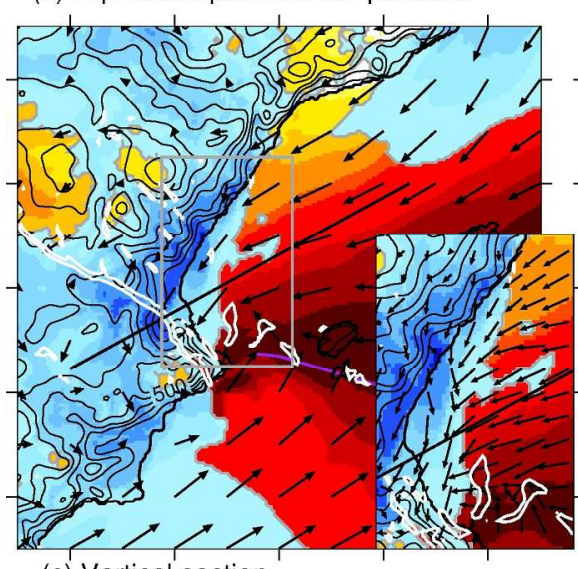

(c) Vertical section

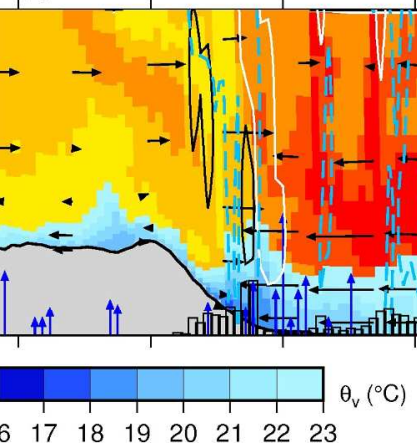

(b) Instantaneous rain rate
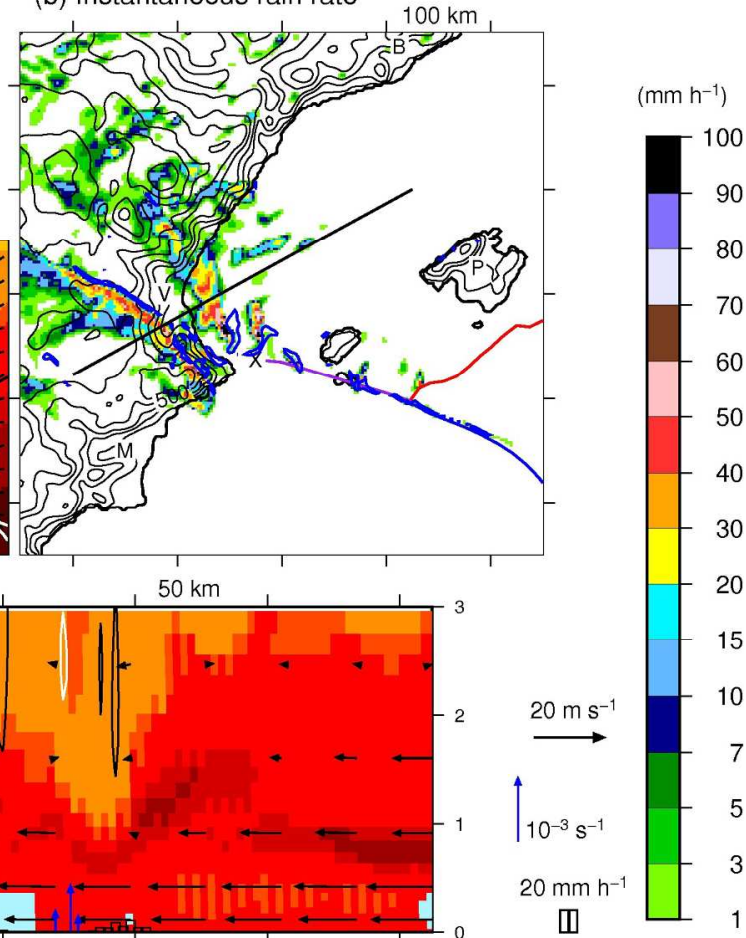

30

31

32

33

34

35

36

37

38

39

40

41

42

43

44

45

46

47

48

49

50

51

52

53

54

55

56

57

58

59

60

Figure 10: Same as Figure 8, but at 2000 UTC on 28 September 2012. The insert in (a) (grey frame) represents in more details the $10-\mathrm{m}$ wind field on the coast at the level of Valencia. 
(a) Equivalent potential temperature

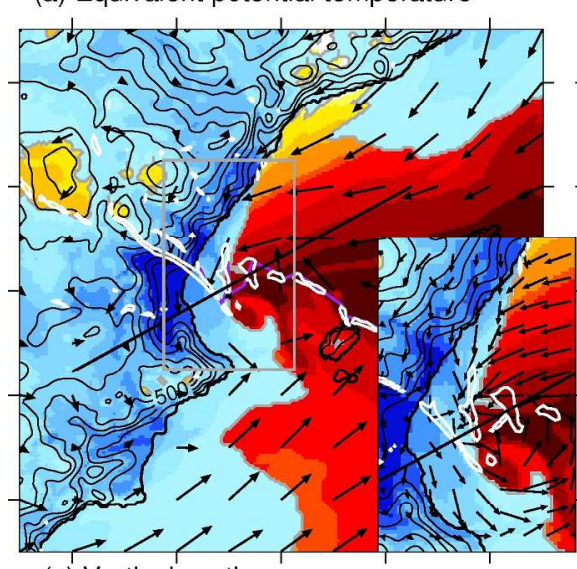

(c) Vertical section

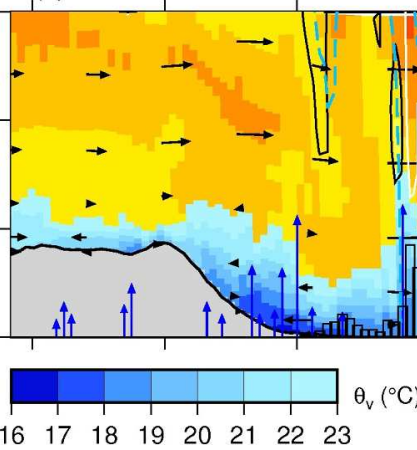

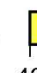

(b) Instantaneous rain rate

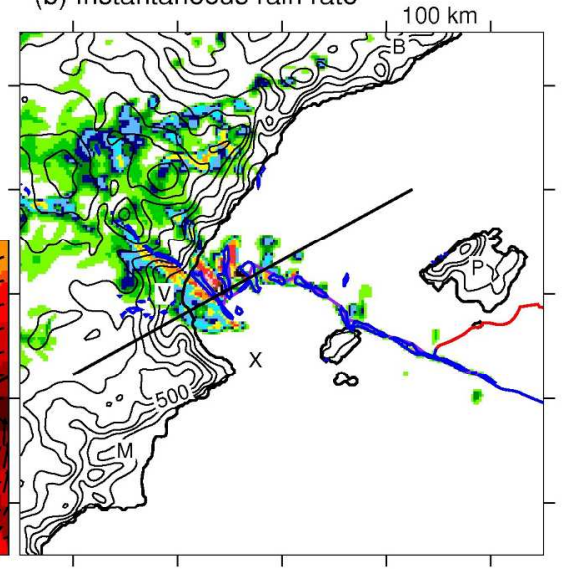

$50 \mathrm{~km}$

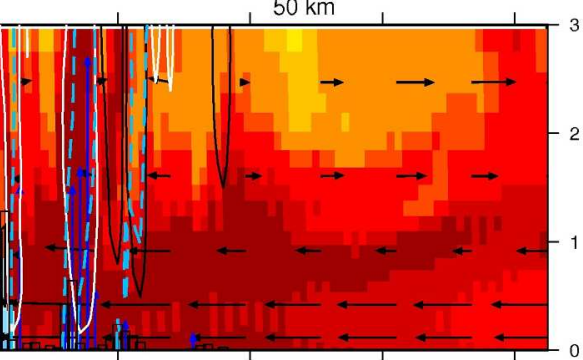
$\begin{array}{lllllllllllll}40 & 42 & 44 & 46 & 48 & 50 & 52 & 54 & 56 & 58 & 60 & 62 & 64\end{array}$

Figure 11: Same as Figure 10, but at 2130 UTC on 28 September 2012. $199 \times 163 \mathrm{~mm}(300 \times 300 \mathrm{DPI})$ 
(a) NOWAV sea-level pressure

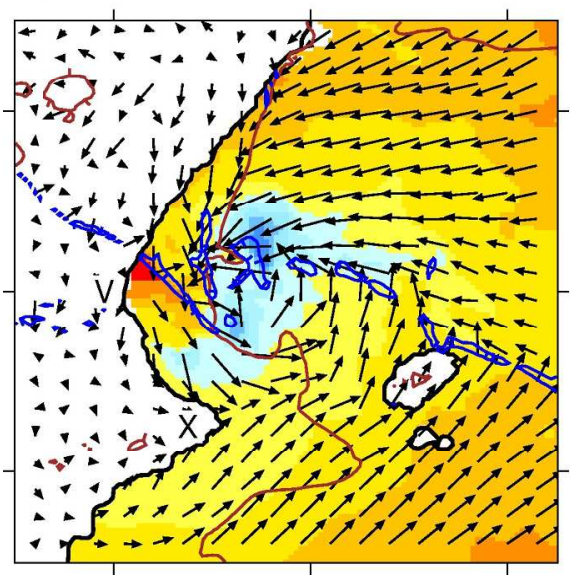

(b) WW3_F sea-level pressure

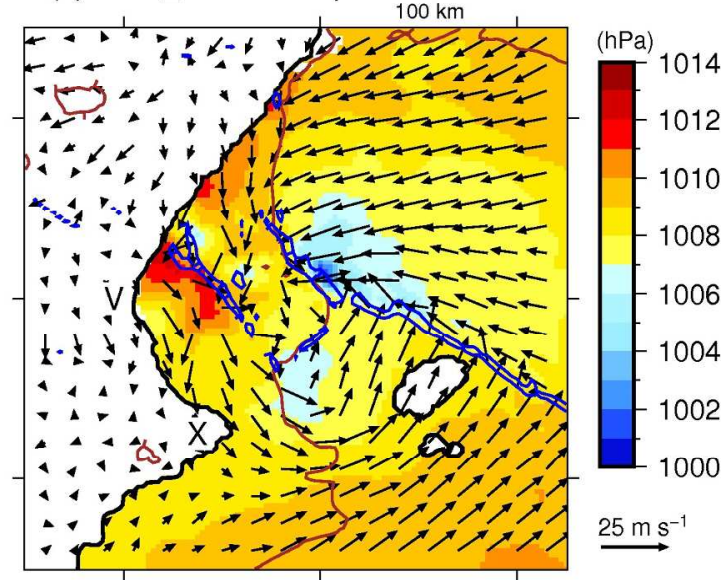

Figure 12: Sea-level pressure (colour scale, hPa), surface wind (black arrows), cold pool edges as identified by $\theta_{v} \leq 23^{\circ} \mathrm{C}$ (brown contour), and areas of moisture convergence rate above $310^{-5} \mathrm{~kg} \mathrm{~m}^{-3} \mathrm{~s}^{-1}$ at the surface (blue contour) from the (a) NOWAV and (b) WW3_F simulations at 2130 UTC, on 28 September 2012. V denotes Valencia, and X Xabia.

$192 \times 91 \mathrm{~mm}(300 \times 300$ DPI $)$ 
(a) OPERA composite radar reflectivities

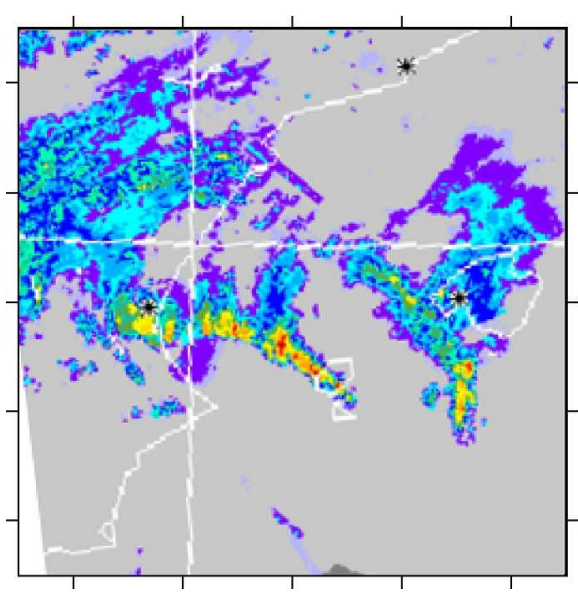

(b) Modelled radar reflectivities

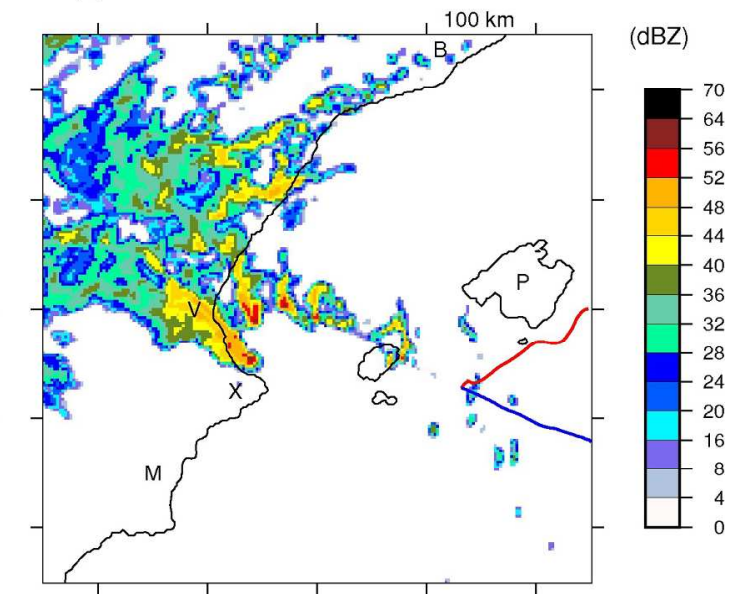

Figure 13: Radar reflectivities (dBZ) at $2000 \mathrm{~m}$ agl in the Valencia region at 2100 UTC on 28 September 2012 (a) from the Odyssey composite product, and (b) from the NOWAV simulation. The red (resp. blue) line indicates the warm (rep. cold) front. V denotes Valencia, B Barcelona, M Murcia, X Xabia, and P Palma de Mallorca.

$190 \times 92 \mathrm{~mm}(300 \times 300$ DPI $)$ 
(a) WW3 wave significant height

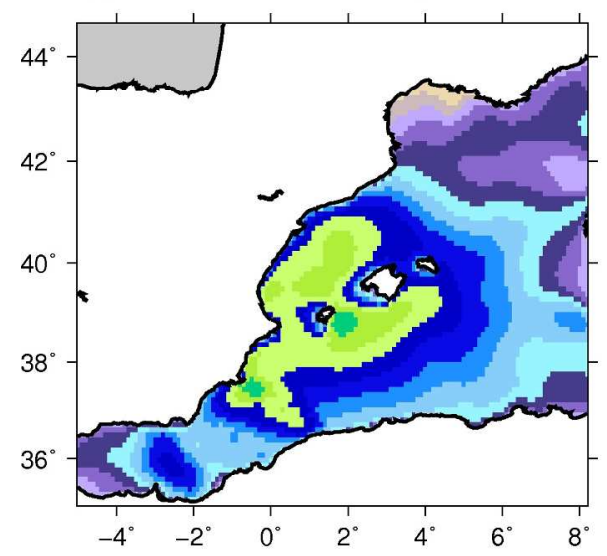

(c) Drag coefficient difference

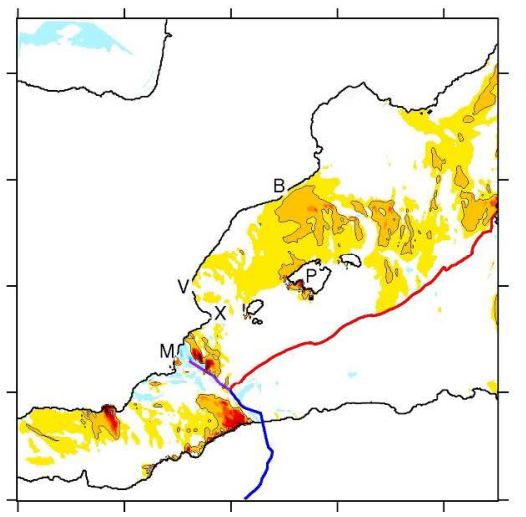

(b) Surface roughness difference

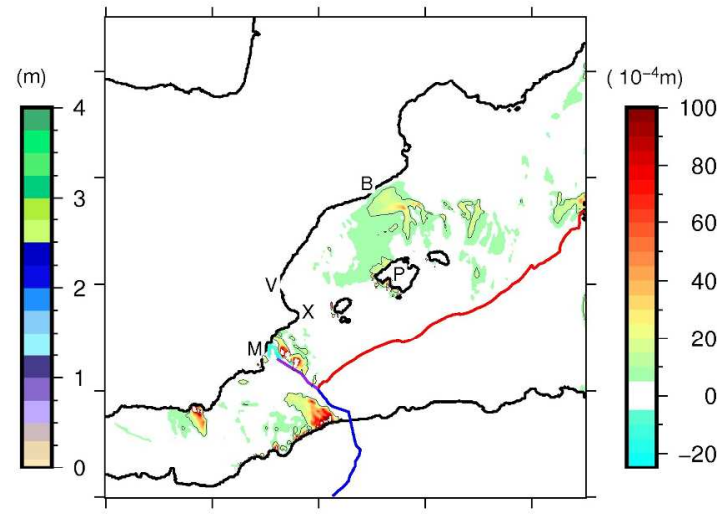

(d) 10-m wind difference

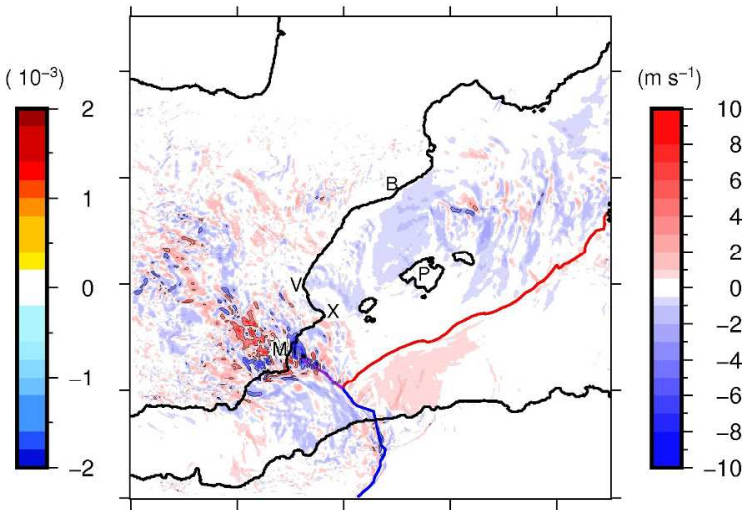

Figure 14: (a) Wave significant height from the Wavewatch III ${ }^{\circ}$ model outputs $(\mathrm{m})$, (b) surface roughness length difference $\left(10^{-4} \mathrm{~m}\right),(\mathrm{c})$ drag coefficient difference $\left(10^{-3}\right)$ and $(\mathrm{d}) 10-\mathrm{m}$ wind speed difference $\left(\mathrm{m} \mathrm{s}^{-1}\right)$ between the WW3_F and NOWAV simulations at 1500 UTC on 28 September 2012. The red (resp. blue) line indicates the warm (rep. cold) front, the purple line the occluded front. $V$ denotes Valencia, B Barcelona, M Murcia, X Xabia, and P Palma de Mallorca. 

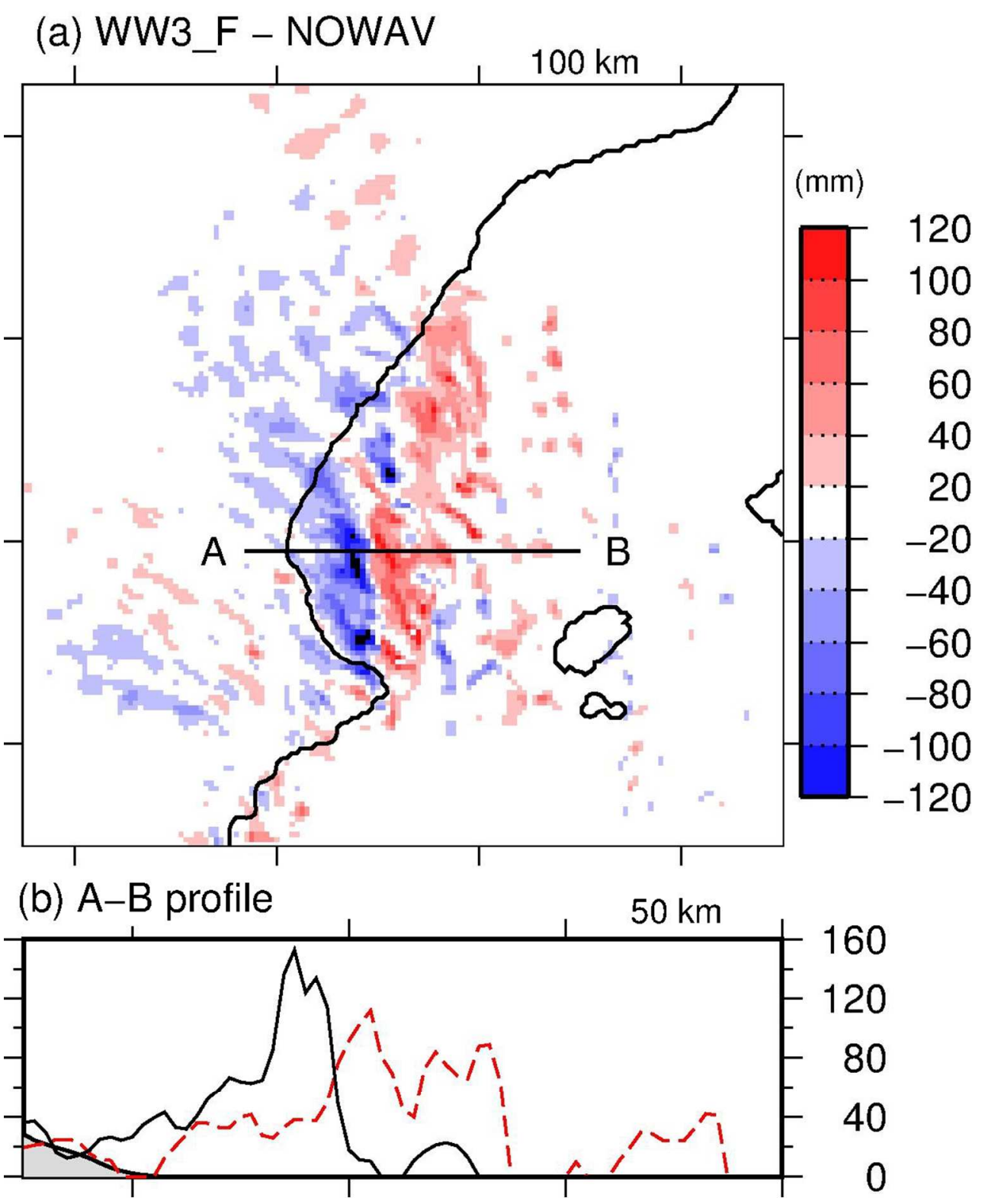

Figure 15: (a) Six-hour cumulated rain difference $(\mathrm{mm})$ between the WW3_F and NOWAV simulations, and (b) six-hour cumulated rain $(\mathrm{mm})$ in the NOWAV (black solid line) and WW3_F (red dashed line) along the A-B profile between 1800 UTC on 28 September 2012 and 0000 UTC on 29 September 2012. 
(a) 28/09/2012 1600 UTC

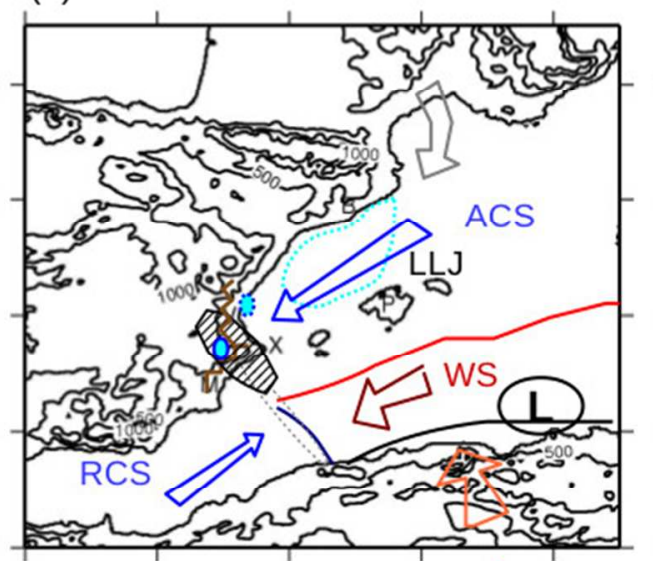

$\square$ Cold and dry flow

$\longrightarrow$ Cold and moist flow

$\bigcirc$ Cold pool (b) $28 / 09 / 20122130$ UTC

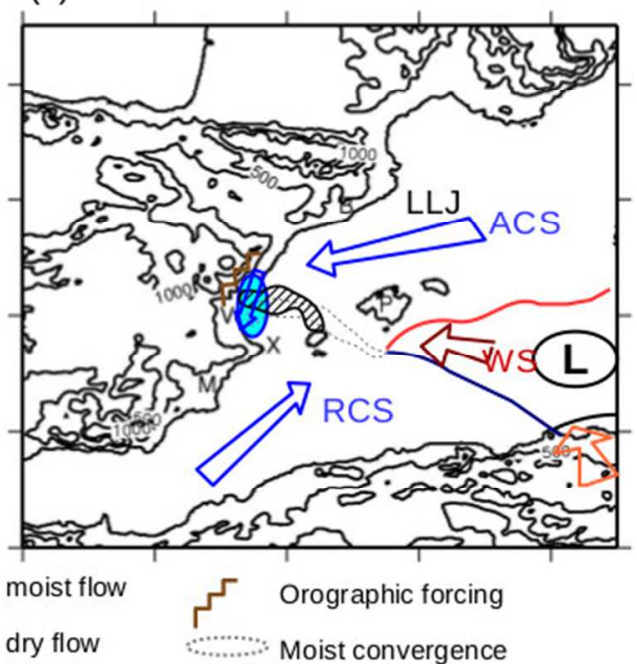

High surface evaporation area

Convective precipitation

Figure 16: Schemes of the low-level flows and forcing mechanisms resulting in heavy precipitation on the Murcia-Valencia region (a) at 1600 UTC and (b) at 2130 UTC on 28 September 2012. The surface cold (warm) front is indicated with a blue (red) line. LLJ corresponds to low-level jet, ACS to ahead cold sector, WS to warm sector and RCS to rear cold sector.

$186 \times 114 \mathrm{~mm}(100 \times 100 \mathrm{DPI})$ 
Processes leading to deep convection and sensitivity to sea-state representation during HyMeX IOP8 heavy precipitation event, M.-N. Bouin ${ }^{*}$, J.-L. Redelsperger, and C. Lebeaupin Brossier

Using numerical simulations, the processes leading to deep convection ad heavy precipitation during the HyMeX-SOP1 IOP8 are investigated. Cold pools and associated inflow deflection play a key role in positioning heavy precipitation, in addition to orographic effects and moisture convergence at sea. Representing in a more realistic way the sea surface roughness results in a displacement of the rain patterns of $50 \mathrm{~km}$ offshore.

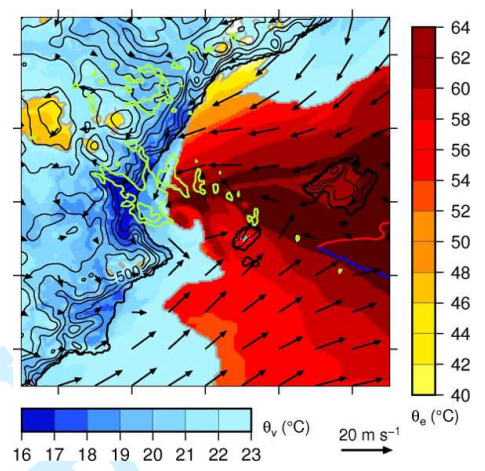

Figure caption: Equivalent potential temperature $\left({ }^{\circ} \mathrm{C}\right)$ and virtual potential temperature $\left({ }^{\circ} \mathrm{C}\right)$ at the surface as a proxy of cold pools, $10-\mathrm{m}$ wind field (arrows) and convective precipitation (green contour) in northeastern Spain at 2130 UTC on the 28 September 2012. 